\title{
Human-environment interaction in the hinterland of Ephesos - as deduced from an in-depth study of Lake Belevi, West Anatolia
}

Friederike Stock ${ }^{1,2^{*}}$, Hannes Laermanns ${ }^{1}$, Anna Pint ${ }^{1}$, Maria Knipping ${ }^{3}$, Sabine Wulf ${ }^{4,5}$, Andreas R. Hassl ${ }^{6}$, Andreas G. Heiss ${ }^{7}$, Sabine Ladstätter ${ }^{7}$, Stephan Opitz ${ }^{1}$, Helmut Schwaiger ${ }^{7}$, Helmut Brückner ${ }^{1 *}$

\author{
${ }^{1}$ Institute of Geography, University of Cologne, Germany \\ ${ }^{2}$ German Federal Institute of Hydrology, Koblenz, Germany \\ ${ }^{3}$ Department of Molecular Botany, Institute of Biology, University of Hohenheim, Germany \\ ${ }^{4}$ School of the Environment, Geography and Geosciences, University of Portsmouth, United Kingdom \\ ${ }^{5}$ Helmholtz Centre Potsdam, German Research Centre for Geosciences GFZ, Section 4.3 Climate dynamics and landscape evolution, Germany \\ ${ }^{6}$ Center for Pathophysiology, Infectiology and Immunology, Medical University of Vienna, Vienna, Austria \\ ${ }^{7}$ Austrian Archaeological Institute, Austrian Academy of Sciences, Vienna, Austria \\ *Corresponding authors: F. Stock, email: stockf@uni-koeln.de; h.brueckner@uni-koeln.de
}

\begin{abstract}
Lacustrine sediments are important archives for high resolution palaeoenvironmental reconstructions of the Holocene. Despite the density of ancient cities and settlements along the western coast of Turkey, the archives from coastal lakes in this area have until now not been recognized to their fullest potential and, therefore, only poorly studied.

The exceptional geo-bio-archive of Lake Belevi is located close to the ancient city of Ephesos in western Turkey. Two sediment cores have been analysed using geochemical, sedimentological, microfaunal, palynological, and archaeoparasitological methods. The in-depth study of these Holocene deposits is supported by a robust age-depth model that used 33 radiocarbon dates and tephrochronology.

The results reveal the existence of a freshwater lake in the Early Holocene which later, due to the rising sea level, was connected to the sea. The delta progradation of the Küçük Menderes resulted again in the development of a freshwater lake. The natural vegetation was represented by open oak woodlands. There are hints for first agricultural activities in the environs of Belevi as early as $8000 \mathrm{cal}$ yr BP. Intensive cultivation of Olea is proven since $3000 \mathrm{cal}$ yr BP. Starting during the $3^{\text {rd }}$ millennium $\mathrm{BP}$, the human impact with enhanced deforestation activities and correlative high sedimentation rates is attested for sites such as Belevi (Ephesos), Elaia (Pergamon) and Miletos. For the first time, tephra from the eruption of Minoan Santorini has been identified in the environs of Ephesos. This ash covered the vegetation by a thick layer, wherefore low-growing plants were strongly affected. The comparison between the results from the quasi natural area of Lake Belevi and the area around the city of Ephesos gives insights into the development and use of the landscapes, the environmental changes as well as the duration and intensity of the human impact.
\end{abstract}

Keywords: lake sediments, Holocene, Western Turkey, Minoan tephra, pollen, microfossils, Ephesos

\section{Introduction}

Lakes are excellent geo-bio-archives for studying climatic and environmental changes during the Pleistocene and the Holocene. Limnic sediments reflect changing climatic conditions brought about by temperature and precipitation changes (Zolitschka, 2007). The detailed analysis of pollen, plant remains, composition of isotopes, chemical parameters and sediments gives insights into the regional climate changes, lake-level fluctuations, vegetation history, ecosystem evolution and the human impact since the Neolithic (Dusar et al., 2011; Stock et al., 2015). In Turkey, inland lakes, such as Lake 
Van (Wick et al., 2003), Lake Gölhisar (Eastwood et al., 2007), Lake Tecer (Kuzucuoğlu et al., 2011), Lake Burdur (Tudryn et al., 2013), Lake Nar (Dean et al., 2015) and Lake İznik (Özturk et al., 2015), have existed at least since the Pleistocene. They render important information, e.g. on the history of the human occupation with agriculture and pastoralism (Dusar et al., 2011; Wilkinson et al., 2014).

In contrast, lakes close to the present coastline were mostly created as a result of Holocene sea-level rise and are therefore much younger. Following the end of the last glaciation, the Holocene transgression led to the formation of large marine embayments. Along with the stabilization of the sea level during the mid-Holocene, rivers in the Mediterranean Region started to form their deltas. For the Aegean coast of Turkey as well as many other coasts of the Mediterranean Sea, an increased delta advance is especially evident during the Roman period. Examples of these are the deltas of the Büyük Menderes (Brückner et al., 2002, 2017; Müllenhoff et al., 2004), the Küçük Menderes (Kraft et al., 1999; Stock, 2015), the Po (Simeone and Corbau, 2009) and the Rhône (Arnaud-Fassetta, 2002). The major reason was most likely increased anthropogenic impact as a result of enhanced deforestation (Dusar et al., 2011; Kaniewski et al., 2013).

In consequence of the delta progradation, coastal and relict or peripheral lakes were formed, which represent parts of the former marine embayment. Later, several of them turned into freshwater lakes and persisted for quite some time. An example of a still existing coastal lake is Las Madres (Zazo et al., 1996; Borja et al., 1999) in southwestern Spain. Relict or peripheral lakes in Western Turkey include Lake Bafa and Lake Azap in the Büyük Menderes Graben (Müllenhoff et al., 2004; Knipping et al., 2008; Herda et al., 2019) as well as Gebekirse Gölü, Akgöl and Lake Belevi in the Küçük Menderes Graben (Fig. 1). Functioning as sediment sinks with permanent infill these lakes serve as favourable geo-bioarchives for palaeoenvironmental reconstructions (Dearing et al., 2006). Lake Belevi in the hinterland of the ancient city of Ephesos, which was intensively studied by means of geoarchaeology (e.g. Brückner 2005, 2019; Kraft et al., 2003, 2011; Stock et al., 2013, 2014, 2019), is an example of such a relict lake (Stock et al., 2015). Due to its protected location in the Küçük Menderes Graben, this lake has archived the environmental history since the Early Holocene transgression. Furthermore, its proximity to one of the most important and most populated cities of the ancient world provides information on the types and amount of human impact on the hinterland of Ephesos. Therefore, this research focuses on the Holocene landscape evolution and vegetation history with special regards to human-environmental interactions as deduced from the geo-bio-archive of Lake Belevi.

\section{Study area}

Located in western Turkey, ca. $60 \mathrm{~km}$ south of Izmir, the study area is part of the Aegean-Anatolian microplate. While the northern drift of the Arabian microplate causes intense folding of the eastern part of the Aegean-Anatolian microplate, its western part is subdued to pressure reduction and a southwestern drift (Polat et al., 2008). This is evidenced by the evolution of several grabens during the Mio-Pliocene, e.g. the grabens of Gediz, Büyük and Küçük Menderes (Doutsos and Kokkalas, 2000; Taymaz et al., 2007).

The Mediterranean climate is characterized by dry and hot summers and humid and mild winters (Finné et al., 2011). Most of the heavy rainfall occurs during the winter months. The mean annual temperature of the city of Selçuk ( $11 \mathrm{~km} \mathrm{SW}$ of Belevi) is $16.4^{\circ} \mathrm{C}$, and the average annual precipitation is $650-780 \mathrm{~mm}$. During the Antiquity, the climate in western Turkey was somewhat colder and drier (Finné et al., 2011).

The vegetation of the study area is characterized by the Olea-Ceratonion zone with wild olive (Olea europaea var. sylvestris (Mill.) Lehr.) and wild carob (Ceratonia siliqua L.) as well as evergreen sclerophyllous taxa (Allen, 2009). Today, intensive agricultural activities dominate the fertile delta plain 
while macchia is found on degraded soils with Pistacia lentiscus L., Quercus coccifera L., Erica arborea L., Arbutus and different Cistus species. More strongly degraded areas are dominated by phrygana (e.g., Sarcopoterium spinosum (L.) Spach and different cushion plants). Phillyrea latifolia L., Pistacia terebinthus L. and Quercus coccifera appear predominantly at elevations $>300 \mathrm{~m}$. Pinus brutia Ten., typical for the coastal region, is widespread not only on degraded soils but also on these elevations. Agricultural and deforestation activities become evident especially since the Bronze Age and the Hellenistic and Roman periods (Dusar et al., 2011; Wilkinson et al., 2014).

Lake Belevi is located within the Küçük Menderes Graben, ca. $20 \mathrm{~km}$ east-northeast of the present coastline and ca. $14 \mathrm{~km}$ east of Ephesos (Fig. 1). The graben is flanked by the Bozdağ and the Aydın Mountain Ranges to the north and south, respectively. In the direct vicinity, the mountains rise to a max. height of $253 \mathrm{~m}$. They mostly consist of mica schists and marbles (Akat and Başarir, 1981).

Lake Belevi has an average northeast-southwest extension of ca. $2.5 \mathrm{~km}$ and a northwest-southeast extension of ca. $1 \mathrm{~km}$. However, the surface area and volume of this very shallow lake vary considerably; but even after the arid months of the summer its maximum water depth still amounts to a few metres (Fig. 1). The Kurutma Canal ( $6 \mathrm{~m}$ wide), built for draining the plain, crosses the lake. It is connected to the Küçük Menderes River (length: 174 km, catchment area: 3586 km²; Akbulut et al., 2009), which follows the graben structure and debouches into the Aegean Sea. Several quarries in the mountains to the north and west of the lake indicate the importance of this area for the nearby ancient city of Ephesos. Marble has been extracted from there since the Antiquity (Prochaska and Grillo, 2009). It was used for several buildings in Ephesos but also for the early Hellenistic mausoleum of Belevi, which is located next to the southern margin of the lake and has recently been studied in detail (Ruggendorfer et al., 2016; Heinz, 2017).

\section{Methods}

\subsection{Fieldwork}

Two sediment cores were retrieved from the southwestern edge of the lake with the percussion corer Cobra pro (Atlas Copco Co.; closed tubes, lengths: 80 and $100 \mathrm{~cm}$, diameter: $6 \mathrm{~cm}$ ): Eph 269 directly at the shore (easting: 40230.272, northing: 4209944.135) and Eph 375 about 180 m away from the shore in the dried out part of the lake (easting: 40160.801, northing: 4209797.725; coordinates in Ephesos Reference Frame 1998 (ERF98); Klotz and Schirmer, 1997; Klotz, 1997). The sediment sequences have a total length of $15.40 \mathrm{~m}$ (Eph 269) and $15.60 \mathrm{~m}$ (Eph 375), respectively (Fig. 2).

\subsection{Laboratory work}

Closed sediment cores were opened in the laboratory of the Institute of Geography of the University of Cologne and sampled in intervals of 2 to $15 \mathrm{~cm}$ for detailed sedimentological, geochemical, microfaunal, palynological and archaeoparasitological analyses.

\subsubsection{Sedimentological, geochemical and microfaunal analyses}

All samples were dried for $72 \mathrm{~h}$ at $40^{\circ} \mathrm{C}$, then pestled and sieved $(<2 \mathrm{~mm}$ for sedimentology and geochemistry). After the removal of the organic content using $15 \% \mathrm{H}_{2} \mathrm{O}_{2}$, granulometric measurements were conducted with a Laser Diffraction Particle Size Analyzer (LS 13320 Beckmann CoulterTM; 116 channels from 0.04 to $2000 \mu \mathrm{m}$ ). Grain-size parameters are based on Folk and Ward (1957) and were calculated with GRADISTAT software version 8 (Blott and Pye, 2001). Magnetic susceptibility (MS) was measured with a Bartington MS2B instrument. Both cores were analysed for $\mathrm{C} / \mathrm{N}$ (=TOC/N; after Meyers and Teranes, 2001). A total of 119 samples were homogenized, weighed in tin boats and measured with a vario EL cube (Elementar Analysensysteme $\mathrm{GmbH}$, Hanau, Germany). 
At first, total carbon (TC) and nitrogen (N) were determined, then another aliquot of each sample was treated with $10 \% \mathrm{HCl}$ for measuring the total organic carbon (TOC).

X-ray fluorescence analysis was conducted on core Eph 269 with an Itrax Core Scanner (Cox Analytical Systems, Sweden; Croudace et al., 2006) in $2 \mathrm{~mm}$ resolution, equipped with a $1.9 \mathrm{~kW}$ chromium ( $\mathrm{Cr}$ ) $\mathrm{X}$-ray tube set to a voltage and current of $30 \mathrm{kV}$ and $30 \mathrm{~mA}$, and an exposure time of 20 seconds.

For microfaunal analyses, 94 samples (ca. $2 \mathrm{~cm}^{3}$ ) with a weight of 5-10 g each were taken from sediment core Eph 269 and 22 samples from Eph 375. Each sample was wet-sieved with a $100 \mu \mathrm{m}$ and a $63 \mu \mathrm{m}$ sieve. Up to 300 individuals per sample were counted and examined for foraminifera according to Meriç et al. (2004) and for ostracods according to Meisch (2000) and Handl et al. (1999). In both sediment cores, 12 species of foraminifers and 19 species of ostracods were identified.

\subsubsection{Palynological analysis}

For pollen analysis, $1-3 \mathrm{~cm}^{3}$ sediment material from 81 samples of core Eph 269 were treated as described in Eisele et al. (1994). Heavy liquid separation was applied to samples with a high mineral part (Eisele et al., 1994), while samples with a low mineral part were treated with HF. Tracer spores (Lycopodium) were added to each sample for calculating the pollen concentration. All samples were cleaned by ultrasonic sieving with a $7 \mu \mathrm{m}$ mesh. Pollen and spore identification were based on the collection of recent pollen and spores at the Institute of Botany, University of Hohenheim (Stuttgart, Germany) and Beug (2004), Moore et al. (1991) and Reille (1992, 1995). In most cases, the counting of at least 300 pollen grains was exceeded. Calculation of the results and plotting of the pollen diagram were done using the software FAGUS (University of Innsbruck, Austria).

\subsubsection{Archaeoparasitological analysis}

Seven samples from Eph 375 (core section $0.02 \mathrm{~m}$ below sea level (b.s.l.; $3.61 \mathrm{~m}$ below surface (b.s.) to $1.79 \mathrm{~m}$ above sea level (a.s.l.; $1.80 \mathrm{~m}$ b.s.)) were dispersed in $5 \mathrm{ml}$ of phosphate borate-saline buffer (PBS) pH 7.2, supplemented with $100 \mu \mathrm{l}$ of a pH neutral detergent (Tween 80). The suspension was centrifuged at $1500 \mathrm{rpm}$ for 5 minutes at room temperature, and the pellet then suspended in $5 \mathrm{ml}$ of a mixture of $89.1 \%$ PBS buffer, $9.1 \%$ glycerol and $1.8 \%$ trypan blue solution (0.4\%, GIBCO). This suspension was poured through a standard household sieve and thereafter through a sieve with a 380 $\mu \mathrm{m}$ mesh size, both thourougly cleaned before use. $100 \mu \mathrm{l}$ of the suspension was meticulously screened in a microscope with a magnification of 100x, using transmitted light and two types of UV light (450-520 nm and 352-448 nm). At least three separate preparations of each sample were evaluated. Parasite stages were identified according to USF Health (2012) and Hassl (2016), counted, and their abundance calculated, if applicable. The calculated lowermost limit of detection was 37 biofacts per gram of sample material.

\subsubsection{Tephrochronological analysis}

Both cores contain visible tephra (volcanic ash) layers that were sampled for glass geochemical studies in order to enable the comparison with dated volcanic events. A total of two tephra samples from each of the cores Eph 269 (2.69-2.22 m b.s.l.; 6.15-5.68 m b.s.) and Eph 375 (1.84-1.77 m b.s.l.; 5.43-5.36 m b.s.) were sieved into a 20-100 $\mu \mathrm{m}$ grain size fraction, embedded in Epoxy resin (Araldite 2020), sectioned and polished for electron probe microanalysis (EPMA). Major element compositions of individual glass shards were obtained on a wavelength dispersive spectrometer (WDS) JEOL JXA-8230 probe at the GFZ Potsdam using an accelerating voltage of $15 \mathrm{kV}$, a beam current of $10 \mathrm{nA}$ and beam sizes of $8 \mu \mathrm{m}$ (samples of Eph 375) and $10 \mu \mathrm{m}$ (sample of Eph 269). Exposure times were 20 seconds for the elements $\mathrm{Fe}, \mathrm{Cl}, \mathrm{Mn}, \mathrm{Ti}, \mathrm{Mg}$ and $\mathrm{P}$, as well as 10 seconds for $\mathrm{Si}, \mathrm{Al}, \mathrm{K}, \mathrm{Ca}$ and $\mathrm{Na}$, analysed first. 
Instrumental calibration used natural mineral and the Lipari obsidian glass standards. Geochemical data were normalised to $100 \%$ on a water-free and volatile-free basis prior to being plotted in bivariate compositional diagrams and then compared with published tephra glass chemical data.

\subsubsection{Radiocarbon dating}

The chronostratigraphy is constrained by 33 ages of $\mathrm{AMS}-{ }^{14} \mathrm{C}$ dated organic material, bulk sediments and shell fragments (Table 1). The age-depth models for both sediment cores were calculated by using the R-based software Bacon 2.2 integrating all ${ }^{14} \mathrm{C}$ age estimates (Blaauw and Christen, 2011). All ages not fitting in this range were marked as outliers.

\section{Results}

\subsection{Sedimentology and geochemistry}

Both sediment cores reveal a similar lithology which can be divided into seven units (A-G) (Fig. 3). The lowermost unit A (only in Eph 375 ) is characterized by poorly sorted light olive brown silty sands with angular stones (quartz, mica schist). The unit is almost void of $\mathrm{Ca}$, and $\mathrm{C} / \mathrm{N}$ is constantly low (1-2). Above, grey sandy silts with shell debris and angular stones at the bottom appear in both sediment cores (unit B1). In Eph 375, this layer is intercalated by organic-rich, very poorly sorted sediments (4; all sorting numbers according to Folk and Ward, 1957). Geochemistry reveals a slightly higher $\mathrm{C} / \mathrm{N}$ ratio ( 2.4), high values of $\mathrm{K}, \mathrm{Fe}, \mathrm{S}$ and Ti/Zr as well as low Ca contents. Unit B1 is overlain by grey silts (poorly sorted: 3 ) with a rising $\mathrm{C} / \mathrm{N}$ ratio $(\sim 10), \mathrm{K}$ and Fe contents that remain high and a decrease in $\mathrm{Ca}$ (unit B2). Especially at the top of this unit, there are increased peaks in MS. A layer of mica-rich fine sand $(\sim 50 \mathrm{~cm})$ is intercalated in the silts in Eph 269 and in peat in Eph 375.

Unit B2 is followed by a $1.07 \mathrm{~cm}$ (Eph 375) to $1.72 \mathrm{~cm}$ (Eph 269) thick yellowish brownish, very poorly sorted silt with an increased sandy component (unit $\mathrm{C}$ ). MS, Fe and $\mathrm{K}$ decrease significantly, whereas $\mathrm{C} / \mathrm{N}$ rises up to 20 , and $\mathrm{Ca}$ and $\mathrm{Fe} / \mathrm{Mn}$ reach their highest values of the core. Organic-rich (peaty) layers with a silty component are characteristic for unit $\mathrm{D}$ in both drill cores from $5 \mathrm{~m}$ b.s.l. to $2 \mathrm{~m}$ a.s.l. MS and $\mathrm{Ca}$ have the lowest values of the sequence, whereas $\mathrm{C} / \mathrm{N}$ (up to 30 ) and $\mathrm{Ti} / \mathrm{Zr}$ (up to $3 \mathrm{k}$ ) ratios rise. Several dark grey clayey silt layers of 2 to $20 \mathrm{~cm}$ thickness are intercalated in the organic-rich strata, correlating with peaks of MS (unit F). Ca decreases considerably, whereas Ti and Fe/Ca peaks occur. The middle part of unit $D$ displays a discrete tephra layer (unit $E$ ), which has a thickness of $\sim 7 \mathrm{~cm}$ in core Eph 375 and $\sim 47 \mathrm{~cm}$ in Eph 269 . The latter comprises a $\sim 3-\mathrm{cm}$-thick basal primary ash deposit (fallout tephra) and a more than $40-\mathrm{cm}$-thick overlying reworked tephra mixed with limnic sediments. Homogeneous olive brown silts with the best sorting (2.8) and with oxidation spots characterize the uppermost part of both drill cores (unit $\mathrm{G}$ ). $\mathrm{Ca}$ and $\mathrm{C} / \mathrm{N}$ are low, while $\mathrm{Fe}, \mathrm{Ca} / \mathrm{Fe}$ and $\mathrm{MS}$ rise considerably in this unit.

\subsection{Micropalaeontology}

The most common foraminifera and ostracod species are Ammonia tepida (Cushman, 1926) and Cyprideis torosa (Jones, 1850), respectively (Fig. 4). Both species live in brackish environments such as lagoons. Less dominant are five other brackish foraminifera and one ostracod species. Limnic ostracods are represented by 13 species, dominated by Candona spp. Bairs, 1845. Some of the identified freshwater ostracods are salt tolerant and common in water bodies close to the coast. Salt-tolerating ostracod species were detected in the lower parts of both cores (units B1, C). In contrast, less salttolerating species occur in the upper part (unit D). Only six different species of marine foraminifera and four different species of marine ostracods were found in the lower part of the profile (unit B2), reflecting a stronger marine influence. Sudden shifts in the microfaunal assemblages roughly coincide 
with the different depositional layers described in section 4.1. The results of the microfaunal analysis were compared with grain size and organic content and combined for statistical evaluation by using a principal component analysis (PCA), implemented using the program PAST (Hammer et al., 2001; Fig. 9).

\subsection{Palynology and archaeoparasitology}

Palynological analyses have been conducted for Eph 269 (Fig. 5, Supplement 2) and for some selected samples of Eph 375. Fig. 5 shows all terrestrial pollen types (100\%) in the main diagram on the left side, and single curves on the right side. Arboreal and non-arboreal pollen types are separated by a thick line. Among the arboreal pollen, the curves of deciduous and evergreen Quercus as well as Olea are displayed, while the right side shows the remaining non-arboreal pollen, Chenopodiaceae-type, Poaceae and Artemisia. The main diagram is followed by single curves of several pollen types. All terrestrial taxa are included in the basic sum with wetland plants, while indeterminables and heavily corroded pollen, spores, and algae are being excluded. Poaceae were included in the terrestrial sum, though a differentiation between local and nonlocal inputs is not possible. Terrestrial pollen types are drawn with filled curves while the excluded types are shown using cross-hatched curves. Only the most frequent or important taxa are presented.

The pollen concentration varies widely depending on the sediment type and their sources. Therefore, the preservation of pollen grains is extremely variable, which was accounted for by clustering them into different preservation groups during counting. Samples with a high content of fluvial material of the Küçük Menderes River reveal in many cases low pollen concentrations along with high amounts of indeterminables or poorly preserved palynomorphs, spores from Isoetes and Pteridium, and pollen of Artemisia (local pollen zone (Ipz) 1a, 1c; sediment units B1, B2). Moreover, in Ipz 1a (sediment unit B1) up to $5 \%$ of Cerealia-type pollen were counted. In contrast to the fluvial-influenced samples, high pollen concentrations were detected in samples with high organic contents (Ipz: 3a, 5-11a; sediment unit D). However, sweet grasses (Poaceae), Chenopodiaceae-type and Artemisia dominate the (nonarboreal) pollen spectra throughout the whole sediment sequence. While most of the Poaceae pollen can be considered of autochthonous origin, a large share of Artemisia pollen is probably allochthonous and brought in by fluvial transport along with many indeterminate pollen grains. Among the arboreal pollen, deciduous oaks dominate; moreover, fewer amounts of river-related taxa (Platanus orientalis L., Alnus orientalis Decne., Fraxinus angustifolia Vahl, Ulmus campestris L., Salix, Tamarix, Vitis sylvestris C.C. Gmel. and Vitex agnus-castus L.; Kürschner et al., 1995) and very few macchia pollen were counted (Ipz 1-3, 5-7). Fragments of charred plant remains rise to the top in variable amounts (Ipz 3, 5-11a). Of special interest is a strongly reduced pollen concentration at a depth of 2.68-2.24 m b.s.I. (Ipz 12; sediment unit E): besides a few pollen grains, only tracer spores of Lycopodium and volcanic glass shards are found. These few pollen grains are from deciduous oaks (Quercus) and alder (Alnus). Only a few herbs and grasses occur and some taxa are absent (e.g., Cladium-type, Plantago, Urtica, Isoetes).

Pollen from deciduous oaks dominate the arboreal taxa up to $1 \mathrm{~m}$ b.s.l. (Ipz 6). An initial slight increase in Olea pollen can be observed from Ipz 2 upwards, if Poaceae as local elements are excluded from the calculation. A considerable increase in Olea, Juglans, Castanea, evergreen oak, Cannabis and poppy pollen occurs in Ipz 8-10b (sediment unit D). Along with the decline of Olea pollen, Pinus pollen increases (Ipz 11-12; sediment unit G). A well-preserved egg of a capillariid nematode, morphologically most similar to the egg of Capillaria aerophila syn. Eucoleus aerophilus (Creplin, 1839) was found at $0.79 \mathrm{~m}$ a.s.l. in core Eph 375 along with some related fragments of a nematode egg with a similar external morphology (1.79 $\mathrm{m}$ a.s.l.). 


\subsection{Chronological data}

\subsubsection{Tephrochronology}

Sediment core Eph 269 contains a $47 \mathrm{~cm}$ thick, white-beige tephra layer at 2.69-2.22 m b.s.l. (6.15$5.68 \mathrm{~m}$ b.s.). While the volcanic glasses are pure in the basal part (2.69-2.66 m b.s.l.; 6.15-6.12 $\mathrm{m}$ b.s.), they are mixed with limnic deposits in the upper part. A similar beige-greyish tephra layer was found in sediment core Eph 375 at 1.84-1.77 m b.s.I. (5.43-5.36 m b.s.). A large number of glass shards was analysed from each tephra layer, i.e. $n=143$ in core Eph 269 and $n=78$ in core Eph 375. Both sample sets reveal an identical homogeneous calc-alkaline, rhyolitic glass composition with concentration ranges in $\mathrm{SiO}_{2}$ and $\mathrm{Al}_{2} \mathrm{O}_{3}$ of 73.4-75.6 wt \% and 13.3-14.3 wt \% (normalized, water- and volatile-free data), and $\mathrm{FeO}$ and $\mathrm{CaO}$ values of 1.7-2.3 wt \% and 1.1-1.6 wt \%, respectively (Fig. 6, Supplement 1).

\subsubsection{Radiocarbon dating}

In total, 33 radiocarbon dates were obtained on peat, bulk sediments, nutshells (Corylus) and seeds from both sediment cores. In case of Eph 269, the calibrated ages cover a time span between $8290 \mathrm{cal}$ yr BP (11.5 m b.s.l.) and 520 cal yr BP (1.17 m a.s.l.). For Eph 375, ages between 8310 cal yr BP $(8.14 \mathrm{~m}$ b.s.I.) and $1080 \mathrm{cal}$ yr BP (1.66 m a.s.l.) were determined. The autoregressive gamma calculations of the Beacon Software excludes five age estimates for Eph 269 and two for Eph 375 from the derived age-depth model (Fig. 7; Blaaw and Christen, 2011). Therefore, these outliers were excluded from the age-depth model. Outliers with younger age estimates in particular, may be related to contamination during drilling. Alternative explanations may involve bioturbation and the use of bulk samples.

\section{Discussion}

\subsection{Facies determination}

Seven different depositional facies and ecozones were determined for both sediment cores based on sedimentological, geochemical and microfaunal data (Figs. 3 and 4 ) as well as their statistical evaluation Fig. 8). A clear distinction can be made between brackish/marine samples of unit B2 and the limnic ones. The PCA shows no difference between limnic sediments of units B1 and D. While the amount of organic matter is high in the phytal zone of unit $D$, the limnic sediments are characterized by a higher amount of sand. Factor 1 (PC 1, 37\%) reflects salinity and is typical for a marine coastal environment. Due to the trigonal distribution pattern, factor 2 (PC 2, $26 \%$ ) can be correlated to a primary factor such as temperature, suggesting climate variability.

\subsubsection{Unit A: Pre-Holocene to Early Holocene terrestrial sediments (until $8400 \mathrm{cal}$ yr BP)}

The sediments of this unit are characterized as light olive brown silty sands with angular quartz and mica schist and are only present at the base of core Eph 375. They are older than 8300 cal yr BP and hence probably originate from the Late Glacial to Early Holocene periods. The samples bear some traces of iron oxide and are barren of microfossils. These brown poorly-sorted heterogeneous sediments (3-5; Folk and Ward, 1957) are of terrestrial origin and most likely represent a colluvium (see Stock et al., 2013). The angular stones were probably transported by heavy rainfall or floods from the surrounding mountains and the hinterland. No evidence of fluvial origin is present. The lack of pollen grains can be explained by a terrestrial environment in which pollen grains do not preserve over a long period.

\subsubsection{Unit B: Limnic-brackish and brackish-marine environments}


The subunits $B 1$ and B2, formed of grey sands and silts, are distinguished by their microfauna assemblage: subunit B1, dating from 8400 to 8000 cal yr BP, is dominated by limnic-brackish ostracods (esp. Candona spp.). Sscarce species of brackish-marine foraminifera (only in core Eph 269: Ammonia spp., Haynesina germanica (Ehrenberg, 1840)) point to a freshwater-brackish environment. The few salt-tolerating species are typical of a nearshore habitat. The low $\mathrm{C} / \mathrm{N}$ ratio indicates an autochthonous aquatic origin (Cohen, 2003; Kausal and Binford, 1999; Meyers and Lallier-Vergès, 1999; Meyers and Teranes, 2002). The high $\mathrm{CaCO}_{3}$ value originates either from authigenic precipitation or the presence of other calcareous organisms (Francke et al., 2013; Kuzucuoğlu et al. 2011). Elevated K and Fe values refer to detrital input from the environs (Arz et al., 1998; Kujau et al., 2010). Thus, a lake developed ca. $8500-8000$ cal yr BP. In core Eph 375 , subunit B1 is intercalated by peat (6.50-6.20 m b.s.l.) pointing to the start of siltation at the shores of the lake. Deciduous oaks (Quercus robur/cerris-type) seem to represent the natural vegetation. More than $5 \%$ of Cerealia-type pollen and a single grain of Linum usitatissimum-type in the lowest pollen sample indicate agricultural activities already at ca. 8400 to 8000 cal yr BP (Stock et al., 2015). However, a differentiation between cultivated and wild cereal grains is not possible (Bottema and Woldring, 1990; Behre, 1990). If the Cerealia-type pollen relate to cultivation, they likely originate from the hinterland from where they were transported into the lake system by fluvial processes.

\subsubsection{Subunit B2: Brackish-marine facies (8000-7000 cal yr BP)}

Subunit B2 is characterized by abundant brackish-marine foraminifera (A. tepida, Ammonia parkinsoniana (d'Orbigny, 1839), H. germanica) and ostracods (C. torosa, Candona spp., Leptocythere sp., Paradoxostoma sp.). Especially $A$. tepida and $C$. torosa indicate marine conditions, correlating with the marine transgression in this area. The results reveal, due to the shift in the coastline, that the lake must have been connected to the sea from ca. 8000 to $7000 \mathrm{cal} \mathrm{yr} \mathrm{BP.} \mathrm{While} \mathrm{the} \mathrm{sea} \mathrm{harbour} \mathrm{city} \mathrm{of}$ Ephesos is located more than ten kilometres further to the southwest (Kraft et al., 2005; Stock et al., 2016), it is noteworthy that within the Küçük Menderes Graben the coastline once reached as far inland as Belevi, i.e. $20 \mathrm{~km}$ to the northeast of the present Aegean Sea. The peaks of magnetic susceptibility as well as the high $\mathrm{K}$ and Fe values point to an enduring detritic input from the nearby environs and the catchment of the Küçük Menderes. This is also indicated by high amounts of indeterminate pollen grains, Isoetes and Artemisia transported by the river as well as poorly and well-preserved pollen (eroded soil/sediments). One pollen grain of Linum usitatissimum-type (self-pollinated, producing few pollen), which has been cultivated in the Eastern Mediterranean region since the early Neolithic (Zohary et al., 2012), as well as Cerealia-type and Secale pollen (weed cereal) may indicate early agricultural activities in this area. Four wild species of Secale are described in Anatolia (Zohary et al., 2012), they can grow as weed in wheat fields, on roadsides or in orchards. Secale was not cultivated on purpose but its development benefited from agricultural activities. Deciduous oaks most likely continue to represent the natural vegetation.

\subsubsection{Unit C: Coastal lake (7000-6700 cal yr BP)}

$A$ distinct boundary separates unit $C$ from the underlying subunit $B 2$. The unit $C$ layer is dominated by $\mathrm{Ca}$ and a rising $\mathrm{C} / \mathrm{N}$ ratio. The strong decrease in marine and brackish-marine species (especially foraminifera) occurred after the lagoon became disconnected from the sea and the river, thus when a coastal lake developed. Lacustrine conditions are indicated by freshwater and lagoonal ostracods $C$. torosa, Candona sp. and $\mathrm{H}$. salina and the freshwater gastropod Gyraulus sp. (Charpentier 1837) This led to strong fluctuations in the salinity which only some species such as $A$. tepida and $C$. torosa could tolerate. An increase in aquatic and swamp plants (macro remains of Ceratophyllum, Najas, Cladium 
mariscus (L.) Pohl) suggest still water conditions. Moreover, the river most likely changed its course as only very few indeterminate pollen grains and spores of Pteridium and Isoetes are present. Cerealiatype (probably as cereal) and other pollen taxa representing agricultural activities decrease. This may be the result of the lack of fluvial input as these pollen probably originated from the hinterland. An influence of pastoral farming with Pistacia, Sarcopoterium-type, Cistus, Juniperus-type, Plantago lanceolata-type and Plantago sp. is possible. Without counting Poaceae (as of local origin), more than $5 \%$ Olea are present indicating a possible onset of olive tree cultivation (Behre, 1990; Beug, 1961; Bottema and Woldring, 1990). The tree-pollen assemblage continues to be dominated by deciduous oaks .

\subsubsection{Unit D: Peat layers (6700-1000 cal yr BP)}

Several peat layers, whose development requires low lakewater level, abundant aquatic and terrestrial plants (Meyers and Lallier-Vergès, 1999; Meyers and Teranes, 2002) and a low energy environment with anoxic conditions (Turney et al., 2005) indicate repeated siltation of the lake. The granulometry of the silty material within the peats is heterogeneous with a poor sorting. The reason may be sediment input from the surrounding slopes. Fluvial input is marginal as Isotetes and Pteridium spores are scarce. The $\mathrm{C} / \mathrm{N}$ ratio rises, while high values of indeterminate pollen grains and iron also indicate erosion from the catchment slopes. The high $\mathrm{C} / \mathrm{N}$ ratio points to the presence of terrestrial plants (Meyers and Teranes, 2002) and are typical for peat bogs (Haberl et al., 2006). The ostracod diversity of limnic species is a clear indication of freshwater conditions of this formerly closed lagoonal lake as represented in the underlying unit $\mathrm{C}$. In the lower part of unit D, phytal species such as Cyclocypris laevis (O.F. Müller, 1776) Sars, 1890 and Pseudocandona sucki (Hartwig, 1901) Danielopol 1980 indicate the beginning of siltation of the water body. Swamp and aquatic plants as well as abundant burnt plant remains are present. It is not clear if the fire residues are a product of natural or humaninduced fires in the dry swamp.

In the upper peat layers of unit D, percentages of Olea pollen increase from 2500 cal yr BP onwards, with one drop and a rise of pastoral farming and/or burning activities at the end of the $3^{\text {rd }}$ millennium BP. Furthermore, Juglans (walnut) was cultivated, and the occurrence of Cannabis and Castanea has been proven. Vitis (grapevine) pollen are less abundant. Therefore, a cultivation of wine cannot be confirmed for the closer environs. In contrast to the wild wine, which is dioecious and wind pollinated, the modern cultivated wine is monoecious and entomophilous. Therefore, a decrease in Vitis pollen does not prove the absence of viticulture either. Bottema and Sarpaki (2003), for example, found only a few pollen even in surface samples of a modern-day vineyard.

In the uppermost part of the peat layers, the amount of Olea pollen decreases, while there is an increase in Pinus pollen. This may hint at an almost treeless vegetation since Pinus pollen can be transported over large distances (Lang, 2004). Another possible scenario would be that pine trees spread subsequently on abandoned land similar to Ephesos (Stock et al., 2016), Elaia (Shumilovskih et al., 2016) or in the environs of the Dead Sea (Heim et al., 1997; Leroy, 2010).

In the peat layer of Eph 375 at ca. $2000 \mathrm{yr}$ cal BP (0.79 m a.s.I.), the detection of a nematode egg, attributable to a species of the family Capillariidae Railliet, 1915 (roundworms), is remarkable because their abundance in the sediment is typically extremely low. Since the egg morphology of capillariid parasites of several free-living or wild host animals is unknown, there is a reasonable chance that the egg may have been produced by an unidentified helminth. C. aerophila is a very common lung parasite of foxes Vulpes spp. Frisch, 1775, wolves (Canis lupus, Linnaeus, 1758), domestic dogs (Canis lupus familiaris), and other carnivorous mammals. It is a currently ubiquitous and prevalent, obligatory parasitic nematode with a direct life cycle that is spread by domestic animal keeping. The lack of polar 
plugs on the egg disproves a recent embedding of the biofact. However, a carry-over of a recent relic in the course of sampling or of a deep deposition of dog feces by rain runoffs cannot be refuted for this particular case.

\subsubsection{Unit E: Tephra layer (ca. 3560 cal yr BP, $1610 \pm 15$ BC)}

The major elements of the glass that composes the tephra layer found in cores Eph 269 and Eph 375 (unit E) are identical and typical for Aegean Arc volcanoes, in particular for the Ash from Santorini (e.g., Federman and Carey, 1980; Kwiecien et al., 2008; Wulf et al., 2020; Fig. 6). The Plinian Minoan eruption occurred at $3560 \pm 15$ cal yr BP, i.e. $1610 \pm 15$ BC (Friedrich et al., 2006) and widely dispersed tephra towards the east (e.g., Athanassas et al., 2018) and northeast (e.g., Druitt et al., 1999; Sulpizio et al., 2013). A younger calibration is discussed by Pearson et al. (2018). In this paper, we used the age $3560 \pm 15$ cal yr BP according to Friedrich et al. (2006). In core Eph 269, the lowermost $3 \mathrm{~cm}$ of the tephra deposit (2.69-2.66 $\mathrm{m}$ b.s.l.) are interpreted as the primary Santorini ash fall. It is directly overlain by a $44-\mathrm{cm}$-thick mixed horizon of tephra shards and silty limnic sediments, which is interpreted as reworked tephra material from catchment inwash and/or lake internal redeposition. In core Eph 375 at 1.84-1.77 m b.s.l., the Santorini Ash forms a homogenous layer and is positioned at a similar chronostratigraphic position within unit D as the equivalent in core Eph 269. Both cores show an increased MS signal at the position of the tephra (Fig. 3). Microfossils are missing throughout the primary and reworked tephra deposits, and only a few pollen grains (deciduous oaks, alder; few herbs and grasses) were detected in the upper, reworked part of the Minoan tephra in core Eph 269.

\subsubsection{Unit F: Intercalated lake sediments (6700-1000 cal yr BP)}

The intercalated grey clayey silt layers (2-20 cm thickness) within the peat of the unit $D$ are interpreted as lacustrine sediments. Low $\mathrm{C} / \mathrm{N}$ ratio points to an aquatic production of plants (Meyers and Teranes, 2002). All lacustrine layers are underlain and overlain by peat indicating lake level fluctuations. ${ }^{14} \mathrm{C}$ age estimates from core Eph 269 date the intercalated lake sediments to 3200 cal yr BP, 2200 cal yr BP, $\sim 1700$ cal yr BP, $\sim 1100$ cal yr BP (i.e. ca. 1250 BC, ca. 250 BC, ca. AD 250, ca. AD 850). The peaks of MS and $\mathrm{Ti}$ in these layers point to detrital/terrestrial input (e.g. Davies et al., 2015). The distinct boundaries between the peat and clayey-silty sediments suggest rapid lake-level changes.

Above the Santorini ash layer in core Eph 269, the amount of limnic ostracods decreases and in one lacustrine sample foraminifera reappear (2.13-2.10 m b.s.l.). At the same time, Isoetes and Polygonum aviculare-type pollen reappear. They originate from the hinterland and were most likely transported by the river. Finds of Artemisia, Plantago lanceolata-type, Plantago sp. and an increase in charred particles indicate increased anthropogenic activities (fire, pasture farming). This short brackish phase is followed by freshwater conditions, as evident from overlying limnic sediments rich in freshwater ostracods (unit F). The origin of this brackish layer is still unknown although several tsunamis occurred in the Mediterranean Region. Thus, a tsunami of another origin than Santorini is well possible (e.g. at ca. 1000 BC in Greece; see Vött et al., 2007).

\subsubsection{Unit G: Alluvium (from 1000 cal yr BP on)}

Unit $\mathrm{G}$ comprises the uppermost part of the cores and consists of beige-brown silts with oxidation spots representing the siltation of the lake margins, starting at about 1200 cal yr BP. Scarce freshwater ostracods from ephemeral, isolated water bodies were only found in the lower parts of the unit. The homogeneous and well sorted sediments (2.8) reveal high Fe values pointing to a terrestrial input (Davies et al., 2015). Cerealia-type pollen are abundant, the amount of Olea pollen slightly rises and 
Pinus dominates the arboreal pollen spectrum. Zea mays (maize, corn) is also present. It has been grown in Turkey and the Euphrates since AD 1574 (Körber-Grohne, 1987).

\subsection{A changing landscape since 8400 cal yr BP - The evolution of lake Belevi and its environs}

The two drill cores from the western shore of Lake Belevi reveal the Holocene landscape evolution. After terrestrial sediments had been deposited in the area of the present-day lake during Postglacial and Early Holocene times, a freshwater lake developed in this part of the Küçük Menderes Graben between 8400 and $8000 \mathrm{cal} \mathrm{yr} \mathrm{BP.} \mathrm{During} \mathrm{the} \mathrm{peak} \mathrm{of} \mathrm{the} \mathrm{Postglacial} \mathrm{sea-level} \mathrm{rise,} \mathrm{the} \mathrm{marine} \mathrm{water}$ reached the lake system and integrated it into the embayment (ca. 8000-7000 cal yr BP). Isoetes spores and indeterminate pollen grains point to fluvial input by the Küçük Menderes River and eroded soil sediments in the hinterland. The vegetation in the environs of the lake/bay was dominated by deciduous oaks.

Around 7000 to $6700 \mathrm{cal} \mathrm{yr} \mathrm{BP}$, a change of the environment is visible in the two cores based on changes in the sediment geochemistry and foraminifera species. It derives from the oscillation of salinity following the disconnection of the open lagoon from the sea, probably due to the delta progradation of the Küçük Menderes River. The lack of fluvial input is reflected by a strong decrease in indeterminate pollen grains and Isoetes spores. The evolution of a closed lagoon is characterized by high precipitation rates of calcium carbonates and the shift to a freshwater lake.

From ca. 6700 to $1500 \mathrm{cal} \mathrm{yr} \mathrm{BP}$ peat dominates, indicating a terrestrial freshwater system at the margins of the lake. Intercalated limnic layers dating to $3200 \mathrm{cal} \mathrm{yr} \mathrm{BP,} 2200 \mathrm{cal} \mathrm{yr} \mathrm{BP}, \sim 1700 \mathrm{cal} \mathrm{yr}$ $\mathrm{BP}, \sim 1100$ cal yr BP (i.e. $\sim 1250 \mathrm{BC}, \sim 250 \mathrm{BC}, \sim 250 \mathrm{AD}, \sim 850 \mathrm{AD}$ ) reflect an oscillating lake level. This may be explained by fluvial input and a displacement of the river bed, inferred from a short phase of increased Isoetes and indeterminates, especially in the upper limnic layers. The highest accumulation rate of sediments occurs ca. 3000-1500 cal yr BP (ca. 1050 BC - AD 450; Fig. 7). This had already been shown for the Küçük Menderes Graben (Stock, 2015), but also for other sites in the Mediterranean region (e.g., Dusar et al., 2011). Especially for deltas - e.g., the ones of the Büyük Menderes (Brückner et al., 2002, 2006; Brückner, 2019), the Rhône (Arnaud-Fassetta, 2002) and the Po (Simeone and Corbau, 2009) - a relatively fast advance during Antiquity has been identified, most likely due to deforestation and other impacts on the natural environment (see also Brückner, 1986, 2020).

The ash of the Santorini eruption is intercalated in the peat layers (3560 cal yr BP or 1610 BC; see section 5.4). A tsunami layer of the eruption is missing. It has been detected in Didyma and Fetiye underlying the Minoan tephra layer and consisting of sands with marine microfossils (Minoura et al., 2000). At that time, the sea was already several kilometres to the west of Belevi (Brückner et al., 2017), and Samos and other islands (e.g., Syrie in the Küçük Menderes Graben) will have attenuated the tsunami waves, wherefore they did not reach as far as Lake Belevi in the hinterland. Overlying the ash layer, a short brackish phase in Eph 269 has been identified, the origin of which is not yet known. Around ca. $1200 \mathrm{cal}$ yr BP (AD 750), the lake started to silt up at its shores, creating today's shallow lake. Its water-level fluctuations are triggered by rainfall, fluvial input, and a canal, which was built in the early $20^{\text {th }}$ century.

\subsection{Human influence}

The human footprint in and around Belevi was by far not as long and intense as in the direct surroundings of Ephesos further seawards. Its existence is, however, evident in the pollen record, the sediment stratigraphy and in archaeological findings. 
The oldest evidence for human settlements in the Ephesia are indicators of agricultural activity. Dating back to the Neolithic period, the pollen record from the settlement mound Çukuriçi Höyük consists of Cerealia-type and Linum pollen along with flax, barley and wheat (Thanheiser, 2008; Stock et al., 2015). A comparable shift from natural to human-impacted vegetation since the Neolithic has also been proven in several other archaeological sites in the Mediterranean region (e.g., Zanchetta et al., 2013). However, at our study site of Belevi, which is located several kilometres in the hinterland of Ephesos, the onset of human impact does not become evident until later: the rise in Olea pollen, Juniperus-type and Juglans dates to ca. 3000 cal yr BP, i.e. after the Bronze Age and is most probably related to the "Beyşehir occupation phase" (van Zeist et al., 1975; Eastwood et al., 1998; cf. Fig. 9). These indicators for pasture farming and land clearance (van Zeist \& Bottema, 1991; Knipping et al., 2008; Shumilovskih et al., 2016) are to a certain extent hidden by the strong increase in Poaceae pollen. The significant human-induced changes in the vegetation coincide with increased sedimentation rates in the research area, estimated from the age-depth models of both cores (Fig. 7). They concur with the Greek, Roman and Byzantine periods when Ephesos experienced its heyday (Ladstätter, 2016). During that time human population in the whole region grew significantly, and so did the need for grain and cattle farming. This caused major clearance activities in the hinterland with the effect of increased soil erosion - and consequently increased sediment accumulation in Lake Belevi and its surrounding areas. The Belevi plain belonged to the sanctuary of Artemis and was settled in villages and scattered farmsteads with a population of farmers and miners (Prochaska and Grillo, 2009). The egg of a capillariid nematode may, therefore, suggest the keeping of domestic dogs for herding.

Beyond indicating an increase of human influence, changes in the pollen spectra and sedimentation pattern also indicate a decrease or sudden decline in human activities. Such a remarkable shift occurs about 1500-1000 cal yr BP, i.e. 450-950 AD, with a sudden spread of pine trees (likely Pinus brutia; Figs. 5,9 ), which were probably growing on abandoned farmland (Stock et al., 2016; Shumilovskih et al., 2016). By then, agricultural activities decline, but are still present. This coincides with the population decline of Ephesos and the Ephesia during the Byzantine period (Ladstätter, 2019).

Nowadays, the area of Belevi is influenced by different human activities, such as extensive mixed farming, marble mining and wattlework production. The railway and highway connections between İzmir and Aydın run past the lake. Although not far from the famous ruins of Ephesos, which are annually visited by hundreds of thousands of tourists, Belevi and its surroundings has remained quite remote.

\subsection{Eruption of Minoan Santorini}

Based on glass geochemical analyses as well as chronostratigraphic constraints, the Minoan tephra has been identified for the first time in the environs of Ephesos, ca. $250 \mathrm{~km}$ northeast of the Santorini volcanic source with a thickness of 3-7 cm (fallout tephra). The ignimbrite deposits have been detected in different geoarchives of the Eastern Mediterranean region (Druitt et al., 2014) and in lakes and lagoons in Anatolia (Sullivan, 1988; Eastwood et al., 1999a, 2007; Sulpizio et al., 2013), e.g. in Lake Gölcük (Sullivan, 1988; Eastwood et al., 1999a; 2002), Lake Gölhisar (Eastwood et al., 2002) and further inland in Lake Acigöl (Sulpizio et al., 2013). Furthermore, the Santorini Ash was discovered at archaeological sites such as Miletos (Huber et al., 2009) and Didyma (10-15 cm; Minoura et al., 2000), in the plain of the Xanthos River (Öner, 1999; Fouache et al., 2012) and during excavations of the coastal site of Bağlararası in Çeşme (Şahoğlu, 2007).

The first discovery of the Santorini tephra in the surroundings of the ancient city of Ephesos sets the Ephesia in the same context as many other sites in this region that were affected by this significant eruption. The widespread occurrence and thickness of the ash layer at this site suggests a large impact 
of the Minoan eruption on the environment, i.e. on the vegetation and lake ecosystem, and hence on the Bronze Age societies. Especially the remarkable decrease in non-arboreal pollen shows how this layer of several centimetres affected the grassland vegetation and eventually the crop growth for a short period of time. This has also been summarized by Neild et al. (1998). Potential effects of ash on crops can be physical impacts (e.g. burning, additional weight, partial burial), rainfall interaction (acid rain) or an alteration of soil chemistry (Neild et al., 1998). Trees may suffer from an ash layer thicker than $100 \mathrm{~mm}$. Wilson et al. (2011) conclude that light ashfall $(<50 \mathrm{~mm})$ may cause slight to severe damage to pastoral farming, but only for a short time. Moreover, lake ecosystems may undergo a nutrient enrichment as described for Lake Gölhisar (Roberts et al., 1997).

\subsection{Regional landscape and vegetation history - comparison with other lakes and ancient cities of the region in Western Turkey}

Sedimentological, microfaunal and palynological investigations of other geo-bio-archives of western Anatolia - such as the basin of the Closed Harbour of Elaia, the maritime satellite of Pergamon/Bergama ca. $150 \mathrm{~km}$ to the north (Pint et al., 2015; Shumilovskih et al., 2016), and Lake Bafa in the Büyük Menderes Graben ca. 50 km to the south (Müllenhoff et al., 2004; Brückner et al., 2017; Herda et al., 2019) - show similar trends. They enable us to set the results from Lake Belevi into a wider context. Lake Marmara (Bulkan et al., 2018) and Lake Sünnet (Ocakoğlu et al., 2013) in northwestern Anatolia were also investigated for the effect of palaeoclimate fluctuations. Lakes on the Anatolian plateau have been studied in detail for the reconstruction of the vegetation, e.g. Lake Gölhisar (Eastwood et al., 1999b) and Lake Sögüt (Roberts, 1990). The latter lakes, however, are located in the interior of Anatolia at an altitude of ca. $1000 \mathrm{~m}$ or higher; thus, they cannot be directly compared to coastal lakes.

The long-stretched grabens of Küçük Menderes and Büyük Menderes, which host Lake Belevi and Lake Bafa, respectively, have experienced major landscape changes during the past seven or so millennia: the filling with marine and fluvial deposits, the westward progradation of their river deltas, the landlocking of former islands, the formation of extended alluvial plains and relict lakes (Brückner, 2019; Brückner et al., 2017). The natural landscapes in lowlands were originally dominated by open deciduous oakwoods, as has been shown for Elaia (Shumilovskih et al., 2016), Milet (Brückner et al., 2006; Herda et al., 2019), while higher elevations were dominated by forests of Quercus ilex-type (Lake Gölhisar, located at $950 \mathrm{~m}$ a.s.l.; Eastwood et al., 1999b) (see compilation in Fig. 9). This has also been confirmed for the Belevi area. Moreover, the first appearance of Cerealia-type pollen can point to human activity as early as the $8^{\text {th }}$ millennium BP. Considering the evolution of the vegetation, all three sites reveal a remarkable vegetation shift with the first major settlement phase associated to agriculture at the end of the $4^{\text {th }} /$ beginning of the $3^{\text {rd }}$ millennium BP (the so-called "Beyşehir occupation phase" in the Iron Age; van Zeist et al., 1975; Eastwood et al., 1998). In the case of Lake Bafa, the substitution of deciduous oakwoods by cultivated land already took place in the second half of the $4^{\text {th }}$ millennium BP (Knipping et al., 2008; Herda et al., 2019). Eastwood et al. (1999b) reported a human impact on the environment in the time span 3350-1250 cal yr BP (1400 BC - AD 700). The harbour archive of Elaia documents the shift from open oakwoods to a cultural landscape - with olive, pistachio and walnut trees, grapes, open woodland and macchia - around $2800 \mathrm{cal}$ yr BP ( 850 BC; Shumilovskih et al., 2016; Fig. 9). This timing of increased human impact is comparable to the site of Belevi where major human activities are proven by a considerable increase in Olea pollen, evergreen oak, Cannabis and poppy pollen for the $3^{\text {rd }}$ millennium BP (Fig. 9). In all cases, Cerealia-type pollen are of only minor importance while Olea dominate, possibly due to an orographic effect. The valley was most likely too 
swampy for cereal cropping so that mainly Olea and some Juglans and Castanea were planted at the slopes and on drier soils.

In comparison to the remote Lake Belevi, which may be considered from the archaeological point of view as an offsite archive, onsite archives are found in the city of Ephesos. There, very strong human impact is proven for the time span ca. 2400-1300 cal yr BP (450 BC - AD 650; Stock et al., 2016). This is mainly due to enhanced deforestation and intensive land-use which resulted in correlated soil erosion leading to increased siltation and a major delta progradation in the lower Küçük Menderes Graben. It may also go together with the founding of the new city of Ephesos in 300 BC and its development as a major economic hub and military base for the Hellenistic kings (Ladstätter, 2016). The intensive exploitation of woodland was even enhanced during the Roman epoch (Heiss and Thanheiser, 2014). Apart from abundant archaeological evidence, this is underlined by the charcoal record of Ephesos (Stock et al., 2016). The findings of different woodland plants, such as Quercus (oak), Fraxinus (ash), Ulmus (elm), Fagus/Platanus (beech/plane) and Olea (olive) clearly show that a large amount of wood was needed in the city for domestic fuel, construction timber, tool-making, ship building, tanning, and last not least, heating the thermal baths. Olea and other fruit trees indicate the clearing of land for cultivation purposes. In Sicily, this has also been proven by Mercuri et al. (2013) and Sadori et al. (2013).

After Antiquity, all sites - e.g., the lakes of Belevi, Bafa and Gölhisar; the cities of Ephesos and Elaia show a decrease of the human footprint in the pollen record. This is mainly due to the population decline and thereby reduced farming activities. The increase in Pinus, probably on abandoned land, was proven for the Late Antiquity and Byzantine times for the site of Belevi and for Ephesos (Stock et al., 2016; Fig. 9) as well as for Lake Bafa ( 1300 cal yr BP, ca. AD 650; Knipping et al., 2008). In Elaia, pine pollen increase from $7-10 \%$ to $46-83 \%$, which is mainly a result of the abandonment of the city ( 1150 cal yr BP, ca. AD 800; Shumilovskih et al., 2016; Fig. 9). The fact that pines replace the original oaks is evidence of soil erosion and degradation, since pines are much less demanding plants than oaks. In other archives in Turkey, such as Lake Gölhisar (Eastwood et al., 1999b) and Gravgaz near Sagalassos (Vermoere et al., 2000), the increase in Pinus pollen can also be seen in the time span of 1500-1000 cal yr BP (450-950 AD; Fig. 9) and at the end of the $2^{\text {nd }}$ millennium BP, respectively. Although both archives (Lake Belevi and Gölhisar) are located at different altitudes, they reveal a similar pattern. As expected, Zea mays (maize) pollen only occur in the pollen profiles during the modern era. Maize has been planted in Turkey since AD 1574 (Körber-Grohne, 1987).

\section{Conclusions}

The palynological record together with sedimentological, geochemical, microfaunal and tephrochronological data of two sediment cores from Lake Belevi provide insights into the Holocene environmental evolution of this lake and its environs. The data reveal vegetation changes and the onset and intensity of the human impact. The development of the lake dates back to $8400 \mathrm{cal} \mathrm{yr}$ BP. The lowermost strata represent a typical sequence of the marine transgression. During the Postglacial sealevel rise, the lake was connected to the sea. Around $7000 \mathrm{cal} \mathrm{yr} \mathrm{BP}$ it was cut off as a result of the delta advance of the Küçük Menderes River. Then followed the transition from a brackish-lagoonal lake to a freshwater coastal lake. The intercalation of several peat and limnic layers indicates lake-level fluctuations. For the first time in the environs of Ephesos, the ash of the Santorini eruption at $3560 \pm 15$ cal yr BP $(1610 \pm 15$ BC) has been detected in the Lake Belevi sediments.

The human-environment interaction is mirrored by the vegetation changes. Around $8000 \mathrm{cal}$ yr BP, the landscape was covered with natural vegetation represented by deciduous oakwoods, while the occurrence of Cerealia-type pollen suggests the first agricultural activities in the hinterland. Increased 
anthropogenic activities resulted in the formation of the so-called secondary plant communities, such as macchia. Starting in the $3^{\text {rd }}$ millennium BP (Iron Age), human impact intensified with strong deforestation for agriculture, pasture farming and the growth of olives and fruit trees, plus the other many reasons why wood was needed mentioned above. This has also been established at other sites in western Turkey. The intensive land use resulted in enhanced soil erosion with higher sedimentation rates in the lake, more rapid delta advance and increased siltation of the marine embayment. With the declining population density in late Antiquity and early Byzantine times, the pressure on the land by exploitation, farming and herding decreased, and pinewoods started to expand. This study shows that even the remote Lake Belevi in the hinterland of Ephesos has archived the human-environment interaction during the past eight millennia, with increased intensity during the third and second last millennia.

\section{Acknowledgements}

We thank the Austrian Archaeological Institute, especially the director Sabine Ladstätter, for the continuous scientific, financial and technical support. The Turkish authorities kindly granted the research permits. Christian Kurtze carried out the DGPS measurements, Michèle Keller and Norman Steinbach analysed samples for geochemistry, sedimentology and microfauna, Volker Wennrich did the XRF measurements, and Oona Appelt helped with the EPMA tephra glass analysis. The Gerda Henkel Foundation provided financial support for the palynological analyses (GHS-AZ 34/V/12), the Austrian National Bank (Oesterreichische Nationalbank) funded the research project "Palynological study of the vegetation and landscape history of the Ephesia" (project number 17134), which is gratefully acknowledged. 


\section{References}

Akat, U., Başarir, E. 1981. 1/25.000 Ölçekli Sayısal Jeoloji Haritaları AYDIN M18-b1 Paftası, Türkiye Jeoloji Veri Tabanı, Jeoloji Etütleri Dairesi Başkanlığı, Maden Tetkik Arama Genel Müdürlüğü, Ankara.

Akbulut, N., Bayarı, S., Akbulut, A., Şahin, Y. 2009. Rivers of Turkey. In: Tockner, K., Uehlinger, U., Robinson, C.T. (eds.): Rivers of Europe. Elsevier, 643-672.

Allen, H. 2009. Vegetation and ecosystem dynamics. In: Woodward, J. (Ed.), The Physical Geography of the Mediterranean. Oxford University Press, Oxford, 203-229.

Arnaud-Fassetta, G. 2002. Geomorphological records of a 'flood-dominated regime' in the Rhône Delta (France) between the 1st century $B C$ and the 2 nd century $A D$. What correlations with the catchment paleohydrology? Geodinamica Acta 15: 79-92.

Arz, H. W., Pätzold, J., Wefer, G. 1998. Correlated millennial-scale changes in surface hydrography and terrigenous sediment yield inferred from last-glacial marine deposits off Brazil. Quaternary Research 50: 157-166.

Athanassas, C.D, Modis, K., Alçiçek, M.C., Theodorakopoulou, K. 2018. Contouring the cataclysm: a geographical analysis of the effects of the Minoan eruption of the Santorini volcano, Environmental Archaeology 23 (2): 160-176.

Behre, K.-E. 1990. Some reflections on anthropogenic indicators and the record of prehistoric occupation phases in the pollen diagrams from the Near East. In: Bottema, S., Entjes-Nieborg, G., van Zeist, W. (eds.). Man's role in the shaping of the Eastern Mediterranean landscape. Balkema, Rotterdam, Brookfield, 219-230.

Beug, H-J. 1961. Beiträge zur postglazialen Floren- und Vegetationsgeschichte Süddalmatiens: Der See „Malo Jezero“ auf Mljet. Flora 150, 600-656.

Beug, H.J. 2004. Leitfaden der Pollenbestimmung. Pfeil: München. 542 pp.

Blaauw, M., Christen, J.C. 2011: Flexible paleoclimate age-depth models using an autoregressive gamma process. Bayesian Analysis 6 (3): 457-474.

Blott, S.J., Pye, K. 2001. GRADISTAT: a grain size distribution and statistics package for the analysis of unconsolidated sediments. Earth Surface Processes and Landforms 26: 1237-1248.

Borja, F., Zazo, C., Dabrio, C.J., Díaz del Olmo, F., Goy, J.L., Lario, J. 1999. Holocene aeolian phases and human settlements along the Atlantic coast of southern Spain. The Holocene 9 (3): 333-339.

Bottema, S., Sarpaki, A. 2003. Environmental change in Crete: a 9000-year record of Holocene vegetation history and the effect of the Santorini eruption. The Holocene 13: 733-749.

Bottema, S., Woldring, H. 1990. Anthropogenic indicators in the pollen record of the Eastern Mediterranean. In: Bottema, S., Entjes-Nieborg, G., van Zeist, W. (eds.). Man's role in the shaping of the Eastern Mediterranean landscape. Balkema, Rotterdam Brookfield, 231-264.

Brückner, H. 1986. Man's impact on the evolution of the physical environment in the Mediterranean region in historical times. GeoJournal 13 (1): 7-17.

Brückner, H. 2005. Holocene shoreline displacements and their consequences for human societies: the example of Ephesos in western Turkey. Zeitschrift für Geomorphologie N. F., Suppl.-Vol. 137: 1122.

Brückner, H. 2019. Rapid delta growth in historical times at Ephesos and Miletus - the examples of the Küçük and the Büyük Menderes rivers. In: Kuzucuoğlu, C. et al. (eds.). Landscapes and Landforms of Turkey, Springer Nature Switzerland, 293-307.

Brückner, H. 2020. Detlas, floodplains, and harbours as geo-bio-archives. Human-environment interactions in western Anatolia. In: Bergemann, J. (ed.). Kultur und Natur in der antiken 
Mittelmeerwelt (Cultura e Natura nel Mediterraneo antico). Göttinger Studien zur Mediterranen Archäologie 9: 37-50.

Brückner, H., Müllenhoff, M., Handl, M., van der Borg, K. 2002. Holocene landscape evolution of the Büyük Menderes alluvial plain in the environs of Myous and Priene (Western Anatolia Turkey). Zeitschrift für Geomorphologie N. F., Suppl.-Vol. 127: 47-65.

Brückner, H., Müllenhoff, M., Gehrels, R., Herda, A., Knipping, M., Vött, A. 2006. From archipelago to floodplain - geographical and ecological changes in Miletus and its environs during the past six millennia (Western Anatolia, Turkey). Zeitschrift für Geomorphologie N. F., Suppl.-Vol. 142: 6383.

Brückner, H., Herda, A., Kerschner, M., Müllenhoff, M., Stock, F. 2017. Life cycle of estuarine islands from the formation to the landlocking of former islands in the environs of Miletos and Ephesos in western Asia Minor (Turkey). Journal of Archaeological Science: Reports 12: 876-894.

Bulkan, Ö., Yalçın, M.N., Wilkes, H. 2018. Geochemistry of Marmara Lake sediments - Implications for Holocene environmental changes in Western Turkey. Quaternary International 486: 199-214.

Cohen, A.S. 2003. Paleolimnology - The History and Evolution of Lake Systems. Oxford University Press, New York. 528 pp.

Croudace, I.W., Rindby, A., Rothwell, R.G. 2006. ITRAX: description and evaluation of a new multifunction X-ray core scanner. Geological Society London Special Publication 267: 51-63.

Davies, S.J., Lamb, H.F., Roberts, S.J. 2015. Micro-XRF core scanning in palaeolimnology. Recent developments. Developments in Paleoenvironmental Research 17: 189-226.

Dean, J.R., Eastwood, W.J., Roberts, N., Jones, M.D., Yiğitbaşoğlu, H., Allcock, S.L., Woodbridge, J., Metcalfe, S.E., Leng, M.J. 2015. Tracking the hydro-climatic signal from lake to sediment: a field study from central Turkey. Journal of Hydrology 529: 608-621.

Dearing, J.A., Battarbee, R.W., Dikau, R., Larocque, I., Oldfield, F. 2006. Human-environment interactions: learning from the past. Regional Environmental Change 6: 1-16.

Doutsos, T., Kokkalas, S. 2000. Stress and deformation patterns in the Aegean region. Journal of Structural Geology 23: 455-472.

Druitt, T.H. 2014. New insights into the initiation and venting of the Bronze-Age eruption of Santorini (Greece), from component analysis. Bulletin of Volcanology 76 (2): 1-21.

Druitt, T.H., Edwards, L., Mellors, R.M., Pyle, D.M., Sparks, R.S.J., Lanphere, M., Davies, M., Barriero, B. 1999. Santorini Volcano. Geological Society London, Memoir, 19. 165 pp.

Dusar, B., Verstraeten, G., Notebaert, B., Bakker, J. 2011. Holocene environmental change and its impact on sediment dynamics in the Eastern Mediterranean. Earth-Science Reviews 108: 137157.

Eastwood, W.J., Roberts, N., Lamb, H.F. 1998. Palaeoecological and archaeological evidence for human occupance in southwest Turkey: The Beyşehir Occupation Phase. Anatolian Studies 48: 69-86.

Eastwood, W.J., Pearce, N.J.G., Westgate, J.A., Perkins, W.T., Lamb, H.F., Roberts, N. 1999a. Geochemistry of Santorini tephra in lake sediments from southwest Turkey. Global and Planetary Change 21: 17-29.

Eastwood, W.J., Roberts, N., Lamb, H.F., Tibby, J.C., 1999b. Holocene environmental change in southwest Turkey: a palaeoecological record of lake and catchment-related changes. Quaternary Science Reviews 18: 671-695.

Eastwood, W.J., Tibby, J., Roberts, N., Birks, H.J.B., Lamb, H.F. 2002. The environmental impact of the Minoan eruption of Santorini (Thera): statistical analysis of palaeoecological data from Gölhisar, southwest Turkey. The Holocene 12: 431-434. 
Eastwood, W.J., Leng, M.J., Roberts, N., Davis, B. 2007. Holocene climate change in the eastern Mediterranean region: a comparison of stable isotope and pollen data from Lake Gölhisar, southwest Turkey. Journal of Quaternary Science 22 (4): 327-341.

Eisele, G., Haas, K., Liner, S. 1994. Methode zur Aufbereitung fossilen Pollens aus minerogenen Sedimenten. In: Frenzel, B. (ed.). Über Probleme der holozänen Vegetationsgeschichte Osttibets. Göttinger Geographische Abhandlungen 95: 165-166.

Federman, A.N., Carey, S.N. 1980. Electron microprobe correlation of tephra layers from Eastern Mediterranean abyssal sediments and the Island of Santorini. Quaternary Research 13: 160-171.

Finné, M., Holmgren, K., Sundqvist, H.S., Weiberg, E., Lindblom, M. 2011. Climate in the eastern Mediterranean, and adjacent regions, during the past 6000 years - a review. Journal of Archaeological Sciences 38, 3153-3173.

Folk, R.L., Ward, W.C. 1957. Brazos River bar: a study in the significance of grain size parameters. Journal of Sedimentary Petrology 27: 3-26.

Francke, A., Wagner, B., Leng, M.J., Rethemeyer, J. 2013. A Late Glacial to Holocene record of environmental change from Lake Dojran Macedonia, Greece. Climate of the Past 9: 481-498.

Friedrich, W.L., Pfeiffer, T., Talamo, S., Kromer, B., Friedrich, M., Heinemeier, J. 2006. Santorini eruption radiocarbon dated to 1627-1600 B.C. Science 312: 548.

Fouache, E., Ecochard, E., Kuzucuoğlu, C., Carcaud, N., Ekmekçi, M., Ulusoy, i., Robert, V., Çiner A., Des Courtils, J. 2012. Palaeogeographical reconstruction and management challenges of an archaeological site listed by UNESCO: the case of the Letoon shrine in the Xanthos Plain (Turkey). Quaestiones Geographicae 31 (1): 37-49.

Haberl, A., Kahrmann, M., Krebs, M., Matchutadze, I., Joosten, H. 2006. The Imnati mire in the Kolkheti lowland in Georgia. Peatlands International 2006/1: 35-38.

Hamann, Y., Wulf, S., Ersoy, O., Ehrmann, W., Aydar, E., Schmiedl, G. 2010. First evidence of a distal early Holocene ash layer in Eastern Mediterranean deep-sea sediments derived from the Anatolian volcanic province. Quaternary Research 73: 497-506.

Hammer, $\varnothing$., Harper, D.A.T., Ryan, P.D. 2001. PAST: Paleontological statistics software package for education and data analysis. Palaeontologia Electronica 4: 9-11.

Handl, M., Mostafawi, N., Brückner, H. 1999. Ostracodenforschung als Werkzeug der Paläogeographie. Marburger Geographische Schriften 134: 116-153.

Hassl, A. 2016. Parasitenstadien im Füllmaterial von mitteleuropäischen Abtritten und Senkgruben: Eine Illustration zur Bestimmung von Peitschenwurm-ähnlichen Wurmeiern. Forum Archaeologiae - Zeitschrift für klassische Archäologie 79/Vl/2016 (https://homepage.univie.ac.at/ andreas.hassl/publikationen/A298.pdf; last access: 11.01.2020).

Heim, C., Nowaczyk, N.R., Negendank, J.F.W., Leroy, S.A.G., Ben-Avraham, Z. 1997. Near East desertification: Evidence from the Dead Sea. Naturwissenschaften 84: 398-401.

Heinz, R. 2017. Das Mausoleum von Belevi. Bauforschung. In: Forschungen in Ephesos 6/1. Austrian Academy of Sciences, Vienna. 498 pp.

Heiss, A.G., Thanheiser, U. 2014. A glimpse of Mediterraneanisation? First analyses of Hellenistic and Roman charcoal remains from Terrace House 2 at Ephesos, and their possible implications for vegetation change, woodland use, and timber trade. In: Open PAGES 2014 Focus 4 Workshop, Leuven, Belgium, 3-7 February, Verstraeten, G. (ed.), Katholieke Universiteit Leuven, Leuven, 2829.

Herda, A., Müllenhoff, M., Brückner, H., Knipping, M. 2019. From the Gulf of Latmos to Lake Bafa: On the history, geoarchaeology, and palynology of the Lower Maeander Valley at the foot of the Latmos Mountains. Hesperia 88: 1-86. 
Huber, H., Bichler, M., Musilek, A. 2009. Identification of pumice and volcanic ash from archaeological sites in the Eastern Mediterranean region. Ägypten und Levante 13: 83-106.

Kaniewski, D., Van Campo, E., Morhange, C., Guiot, J., Zviely, D., Shaked, I., Otto, T., Artzy, M. 2013. Early urban impact on Mediterranean coastal environments. Science Reports 3: 3540.

Kaushal, S., Binford, M.W. 1999. Relationship between C:N ratios of lake sediments, organic matter sources, and historical deforestation in Lake Pleasant, Massachusetts, USA. Journal of Paleolimnology 22: 439-442.

Klotz, S., Schirmer, C. 1997. Ein digitaler Stadtplan von Ephesos. In: Forum Archaeologiae - Zeitschrift für klassische Archäologie 5/XII/1997 (http://homepage. univie.ac.at/elisabeth.trinkl/forum/ forum1297/05digi.htm; last access: 18.12.2019).

Klotz, S. 1997. Grabungsbericht Ephesos 1997 - Vermessung. Österreichische Jahreshefte 67: 37-39.

Knipping, M., Müllenhoff, M., Brückner, H. 2008. Human induced landscape changes around Bafa Gölü (Western Turkey). Vegetation History and Archaeobotany 17: 365-380.

Körber-Grohne, U. 1987. Nutzpflanzen in Deutschland. Kulturgeschichte und Biologie. Theiss, Stuttgart. $490 \mathrm{pp}$.

Kraft, J.C., Brückner, H., Kayan, i. 1999. Palaeogeographies of ancient coastal environments in the environs of the Feigengarten excavation and the 'Via(e) Sacra(e)' to the Artemision at Ephesos. In: Steine und Wege. Festschrift für Dieter Knibbe zum 65. Geburtstag, Scherrer, P., Taeuber, H., Thür, H. (eds.). Österreichisches Archäologisches Institut, Wien, Sonderschriften 32: 91-100.

Kraft, J.C., Rapp, G., Kayan, I., Luce, J.V. 2003. Harbor areas at ancient Troy: Sedimentology and geomorphology complement Homer's Iliad. Geology 31: 163-166.

Kraft, J.C., Brückner, H., Kayan, I. 2005. The sea under the city of ancient Ephesus. In: Synergia. Festschrift Friedrich Krinzinger, Brandt, B., Gassnerm V,, Ladstätter, S. (eds.). Phoibos: Wien; vol. 1: 147-156.

Kujau, A., Nürnberg, D., Zielhofer, C., Bahr, A., Röhl, U. 2010. Mississippi River discharge over the last $\sim 560,000$ years - Indications from X-ray fluorescence core-scanning. Palaeogeography, Palaeoclimatology, Palaeoecology 298: 311-318.

Kürschner, H., Raus, T., Venter, J. 1995. Pflanzen der Türkei. Ägäis - Taurus - Inneranatolien. Quelle and Meyer, Wiesbaden

Kuzucuoğlu, C., Dörfler, W., Kunesch, S., Goupille, F. 2011. Mid- to late-Holocene climate change in central Turkey: the Tecer Lake record. The Holocene 21(1): 173-188.

Kwiecien, O., Arz, H.W., Lamy, F., Wulf, S., Bahr, A., Röhl, U., Haug, G.H. 2008. Estimated reservoir ages of the Black Sea since the last Glacial. Radiocarbon 50: 1-20.

Ladstätter, S. 2016. Hafen und Stadt von Ephesos in hellenistischer Zeit. Österreichische Jahreshefte 85: $233-272$.

Ladstätter, S. 2019. Ephesos from Late Antiquity until the Middle Ages. An archaeological introduction. In: Ladstätter, S., Magdalino, P. (eds.). Ephesos from Late Antiquity until the Late Middle Ages, Sonderschriften des Österreichischen Archäologischen Institutes 58, 11-72.

Lang, G. 1994. Quartäre Vegetationsgeschichte Europas. G. Fischer, Jena Stuttgart New York. 462 p.

Le Bas, M.J., Le Maitre, R.W., Streckeisen, A., Zanettin, B. 1986. A chemical classification of volcanic rocks based on the total alkali-silica diagram. Journal of Petrology 27: 745-750.

Leroy, S.A.G. 2010. Pollen analysis of core DS7-1SC (Dead Sea) showing intertwined effects of climatic change and human activities in the Late Holocene. Journal of Archaeological Science 37: 306-316.

Meisch, C. 2000. Ostracoda. In: Süßwasserfauna von Mitteleuropa: Bd. 8, Crustacea. Schwoerbel, J., Zwick, P. (eds.), Spektrum: Heidelberg. 522 pp. 
Mercuri, A.M., Bandini Mazzanti, M., Florenzano, A., Montecchi, M.C., Rattighieri, E. 2013. Olea, Juglans and Castanea: the OJC group as pollen evidence of the development of human-induced environments in the Italian peninsula. Quaternary International 303: 24-42.

Meriç, E., Avşar, N., Bergin, F. 2004. Benthic foraminifera of eastern Aegean sea (Turkey) - systematics and autoecology. Turkish Marine Research Foundation 18: 1-306.

Meyers, P.A., Lallier-Vergès, E. 1999. Lacustrine sedimentary organic matter records of Late Quaternary paleoclimates. Journal of Paleolimnology 21: 345-372.

Meyers, P.A., Teranes, J.L. 2002. Sediment organic matter. In: Last, W.M., Smol, J.P. (eds.). Tracking Environmental Change Using Lake Sediments, Vol. 2: Physical and Geochemical Methods. Kluwer Academic Publishers: Dordrecht. 504 pp.

Minoura, K., Imamura, F., Kuran, U., Nakamura, T., Papadopoulos, G.A., Takahashi, T., Yalciner, A.C. 2000. Discovery of Minoan tsunami deposits. Geology 28: 59-62.

Moore, P.D., Webb, J.A., Collinson, M.E. 1991. Pollen analyses. Blackwell: Oxford. 216 pp.

Müllenhoff, M., Handl, M., Knipping, M., Brückner, H. 2004. The evolution of Lake Bafa (Western Turkey) - sedimentological, microfaunal and palynological results. Coastline Reports 1: 55-66.

Neild, J., O'Flaherty, P., Hedley, P., Underwood, R., Johnson, D., Christenson, B., Brown, P. 1998. Impact of a volcanic eruption on agriculture and forestry in New Zealand. New Zealand Ministry of Agriculture and Forestry Technical Paper 99/2.

Ocakoğlu, F., Kır, O., Yılmaz, I.Ö., Açıkalın, S:, Erayık, C., Tunoğlu, C., Leroy, S.A.G. 2013. Early to MidHolocene lake level and temperature records from the terraces of Lake Sünnet in NW Turkey. Palaeogeography, Palaeoclimatology, Palaeoecology 369: 175-184.

Öner, E. 1999. Letoon ve çevresinde (Eşen çayı deltası) paleojeomofolojik araştırmalar. Ege Coğrafya Dergisi 10: 51-82.

Özturk, M.Z., Erginal, A.E., Kiyak, N.G., Demirci, A., Ekinci, Y.L., Curebal, I, Avcıoglu, M., Ozturk, T. 2015. Records of repeated drought stages during the Holocene, Lake Iznik (Turkey) with reference to beachrock. Quaternary International 408: 16-24.

Pearson, C.L., Brewer, P.W., Brown, D., Heaton, T.J., Hodgins, G.W.L., Jull, A.J.T., Lange, T., Salzer, M.W. 2018. Annual radiocarbon record indicates 16th century BCE date for the Thera eruption. Science Advances Volume 4 (8): eaar8241.

Pint, A., Seeliger, M., Frenzel, P., Feuser, S., Erkul, E., Berndt, C., Klein, C., Pirson, F., Brückner, H. 2015. The environs of Elaia's ancient open harbour - a reconstruction based on microfaunal evidence. Journal of Archaeological Sciences 54: 340-355.

Polat, O., Gok, E., Yilmaz, D. 2008. Earthquake hazard of the Aegean extension region (West Turkey). Turkish Journal of Earth Sciences 17: 593-614.

Prochaska, W., Grillo, S.M. 2009. A new method for the determination of the provenance of white marbles by chemical analysis of inclusion fluids: the marbles of the Mausoleum of Belevi/Turkey. Archaeometry 52 (1): 59-82.

Reille, M. 1992. Pollen et spores d'Europe et d'Afrique du Nord. Laboratoire de Botanique historique et Palynologie: Marseille. 543 pp.

Reille, M. 1995. Pollen et spores d'Europe et d'Afrique du Nord. Supplement 1. Laboratoire de Botanique historique et Palynologie: Marseille. 543 pp.

Reimer, P.J., Bard, E., Bayliss, A., Beck, J.W., Blackwell, P.G., Bronk Ramsey, C., Buck, C.E., Cheng, H., Edwards, R.L., Friedrich, M., Grootes, P.M., Guilderson, T.P., Haflidason, H., Hajdas, I., Hatté, C., Heaton, T.J., Hoffmann, D.L., Hogg, A.G., Hughen, K.A., Kaiser, K.F., Kromer, B., Manning, S.W., Niu, M., Reimer, R.W., Richards, D.A., Scott, E.M., Southon, J.R., Staff, R.A., Turney, C.S.M., van 
der Plicht, J. 2013. IntCal13 and Marine13 radiocarbon age calibration curves, 0-50,000 years cal BP. Radiocarbon 55(4): 1869-1887.

Roberts, N. 1990. Human-induced landscape change in south and southeast Turkey during the later Holocene. In: Bottema, S., Entjes-Nieborg, G., van Zeist, W. (eds.). Man's role in the Shaping of the Eastern Mediterranean Landscape. A.A. Balkema: Rotterdam, 53-67.

Roberts, N., Eastwood, W.J., Lamb, H.F., Tibby, J.C. 1997. The age and causes of mid-Holocene environmental change in southwest Turkey. In: Dalfez, H.N., Kukla, G., Weiss, W. (eds.) Third Millennium BC climate change and the Old World Collapse. Proceedings of NATO ASI Series I, vol. 49, Springer, 409-429.

Ruggendorfer, P., Forstenpointner, G-. Galik, A., Kanz, F., Pfisterer, M., Prochaska. W., Schätzschock, M., Taeuber, H., Trapichler, M., Weissengruber, G.E. 2016. Das Mausoleum von Belevi. Archäologische Untersuchungen zu Chronologie, Ausstattung und Stiftung. Forschungen in Ephesos 6/2. Austrian Academy of Sciences, Vienna.

Sadori, L., Ortu, E., Peyron, O., Zanchetta, G., Vannière, B., Desmet, M., Magny, M. 2013. The last 7 millennia of vegetation and climate changes at Lago di Pergusa (central Sicily, Italy). Climate of the Past 9: 1969-1984.

Şahoğlu, V. 2007. Çeşme-Bağlararası: A new excavation in Western Anatolia. In: Felten, F., Gauss, W., Smetana, R. (eds.): Middle Helladic Pottery and Synchronisms, Proceedings of the International Workshop held at Salzburg October 31 - November 2, 2004. Vienna: Austrian Academy of Sciences Press, 309-322.

Shumilovskih, L.S., Seeliger, M., Feuser, S., Novenko, E., Schlütz, F., Pint, A., Pirson, F., Brückner, H. 2016. The harbour of Elaia: a palynological archive for human environmental interactions during the last 7500 years. Quaternary Science Reviews 149: 167-187.

Siani, G., Paterne, M., Arnold, M., Bard, E., Metivier, B., Tisnerat, N., Bassinot, F. 2000. Radiocarbon reservoir ages in the Mediterranean Sea and Black Sea. Radiocarbon 42: 271-280.

Simeone, U., Corbau, C. 2009. A review of the Delta Po evolution (Italy) related to climatic changes and human impacts. Geomorphology 107: 64-71.

Stock, F., 2015. Ephesos and the Ephesia - palaeogeographical and geoarchaeological research about a famous city in Western Anatolia. PhD dissertation, University of Cologne, 155 pp.; http://kups.ub.uni-koeln.de/6368/.

Stock, F., Pint, A., Horejs, B., Ladstätter, S., Brückner, H. 2013. In search of the harbours: new evidence of Late Roman and Byzantine harbours of Ephesos. Quaternary International 312: 57-69.

Stock, F., Kerschner, M., Kraft, J.C., Pint, A., Frenzel, P., Brückner, H. 2014. The palaeo-geographies of Ephesos (Turkey), its harbours and the Artemision - a geoarchaeological reconstruction for the timespan 1500-300 BC. Zeitschrift für Geomorphologie N. F. 58, Supplementary Issue 2: 33-66.

Stock, F., Ehlers, L., Horejs, B., Knipping, M., Ladstätter, S., Seren, S., Brückner, H. 2015. Neolithic settlement sites in Western Turkey - palaeogeographic studies at Çukuriçi Höyük and Arvalya Höyük. Journal of Archaeological Science: Reports 4: 565-577.

Stock, F., Knipping, M., Pint, A., Ladstätter, S., Delile, H., Heiss, A.G., Laermanns, H., Mitchell, P., Ployer, R., Steskal, M., Thanheiser, U., Urz, R., Wennrich, V., Brückner, H. 2016. Human impact on Holocene sediment dynamics in the Eastern Mediterranean - the example of the Roman harbour of Ephesos. Earth Surface Processes and Landforms 41: 980-996.

Stock, F., Halder, S., Opitz, S., Pint, A., Seren, S., Ladstätter, S., Brückner, H. 2019. Late Holocene coastline and landscape changes to the west of Ephesos, Turkey. Quaternary International 501: 349-363.

Sullivan, D.G. 1988. The discovery of Santorini Minoan tephra in western Turkey. Nature 333: 552-554. 
Sulpizio, R., Alcicek, M.C., Zanchetta, G., Solari, L. 2013. Recognition of the Minoan tephra in the Acigöl Basin, western Turkey: implications for inter-archive correlations and fine ash dispersal. Journal of Quaternary Science 28 (4): 329-335.

Taymaz, T., Yilmay, Y., Dilek, Y. 2007. The geodynamics of the Aegean and Anatolia: Introduction. Geological Society London, Special Publications 291: 1-16.

Thanheiser, U. 2008. Erster Grabungsbericht zu den Kampagnen 2006 und 2007 am Çukuriçi Höyük bei Ephesos. Erste Ergebnisse der botanischen Analysen. Jahreshefte des Österreichischen Archäologischen Institutes in Wien 77: 102-103.

Tomlinson, E.L., Kinvig, H.S., Smith, V.C., Blundy, J.D., Gottsmann, J., Müller, W., Menzies, M.A. 2012. The Upper and Lower Nisyros Pumices: revisions to the Mediterranean tephrostratigraphic record based on micron-beam glass geochemistry. Journal of Volcanology and Geothermal Research 243-244: 69-80.

Tomlinson, E.L., Smith, V.C., Albert, P.G., Aydar, E., Civetta, L., Cioni, R., Cubukcu, E., Gertisser, R., Isaia, R., Menzies, M.A., Orsi, G., Rosi, M., Zanchetta, G. 2015. The major and trace element glass compositions of the productive Mediterranean volcanic sources: tools for correlating distal tephra layers in and around Europe. Quaternary Science Reviews 118: 48-66.

Tudryn, A., Tucholka, P., Özgûr, N., Gibert, E., Elitok, O., Kamaci, Z., Massault, M., Poisson, A., Platevoet, B. 2013. A 2300-year record of environmental change from SW Anatolia, Lake Burdur, Turkey. Journal of Paleolimnology 49: 647-662.

Turney, C., Canti, M., Branch, N., Clark, P. 2005. Environmental archaeology: theoretical and practical approaches. Routledge, London, UK. 256 pp.

USF Health 2012. Diagnosis of helminth infections. net-publication: 1-7. (http://hsc.usf.edu/NR/rdonlyres/ F8F4B926-4DDD-4531-9A27-1299CCCA80C6/0/HelminthKey. pdf; last access: 12.12.2019).

Vött, A., Brückner, B., May, M., Lang, F., Brockmüller, S. 2007. Late Holocene tsunami imprint at the entrance of the Ambrakian gulf (NW Greece). Impacts des tsunamis le long des côtes du golfe Ambracien (Grèce nord-occidentale). Méditerrannée 108: 43-57.

Wick, L., Lemcke, G., Sturm, M. 2003. Evidence of Lateglacial and Holocene climatic change and human impact in eastern Anatolia: high-resolution pollen, charcoal, isotopic and geochemical records from the laminated sediments of Lake Van, Turkey. The Holocene 13 (5): 665-675.

Wilkinson, I.P., Poirier, C., Head, M.J., Sayer, C.D., Tibby, J. 2014. Micropalaeontological signatures of the Anthropocene. In: Waters, C.N., Zalasiewicz, J., Williams, M., Ellis, M.A., Snelling, A. (eds.), A Stratigraphical Basis for the Anthropocene. Geological Society London, Special Publications 395: 185-219.

Wilson, T., Cole, J., Cronin, S., Stewart, C., Johnston, D. 2011. Impacts on agriculture following the 1991 eruption of Vulcan Hudson, Patagonia: lessons for recovery. Natural Hazards 57 (2): 185-212.

Wulf, S., Kraml, M., Kuhn, T., Schwarz, M., Inthorn, M., Keller, J., Kuscu, I., Halbach, P. 2002. Marine tephra from the Cape Riva eruption (22 ka) of Santorini in the Sea of Marmara. Marine Geology 183: 131-141.

Wulf, S., Keller, J., Satow, C., Gertisser, R., Kraml, M., Grant, K.M., Appelt, O., Vakhrameeva, P., Koutsodendris, A., Hardiman, M., Schulz, H., Pross, J. 2020. Advancing Santorini's tephrostratigraphy: new glass geochemical data and improved marine-terrestrial tephra correlations for the past 360 kyrs. Earth-Science Reviews 200: 102964.

van Zeist, W, Woldring, H, Stapert, D., 1975. Late Quaternary vegetation and climate of southwestern Turkey. Palaeohistoria 17, Bussum. 
van Zeist, W., Bottema, S., 1991. Late Quaternary vegetation of the Near East. Beihefte zum Tübinger Atlas des Vorderen Orients (TAVO) 18A, 156 pp.

Vermoere, M., Smets, E., Waelkens, M. Vanhaverbeke, H., Librecht, I., Paulissen, E., Vanhecke, L. 2000. Late Holocene Environmental Change and the Record of Human Impact at Gravgaz near Sagalassos, Southwest Turkey. Journal of Archaeological Science 27(7): 571-595.

Zanchetta, G., Bini, M., Crematschi, M., Magny, M., Sadori, L., 2013. The transition from natural to anthropogenic-dominated environmental change in Italy and the surrounding regions since the Neolithic: an introduction. Quaternary International 303: 1-9.

Zazo, C., Lezine, A.M., Borja, F., Denefle, M., Dabrio, C.J., Lario, J., Rodríguez Vidal, J., Goy, J.L., Díaz del Olmo, F., Cáceres, L., Clemente, L., Baeteman, C., Rodríguez, A. 1996. Holocene coastal progradation changes and peat bog development in SW Spanish Coast. INQUA Mediterranean and Black Sea Shorelines Subcommission Newsletter 18: 13-17.

Zohary, D., Hopf, M., Weiss, E. 2012. Domestication of Plants in the Old World. Oxford University Press, Oxford. 264 pp.

Zolitschka, B. 2007. Varved Lake Sediments. Encyclopedia of Quaternary Science. Elsevier, Amsterdam, 3105-3114. 


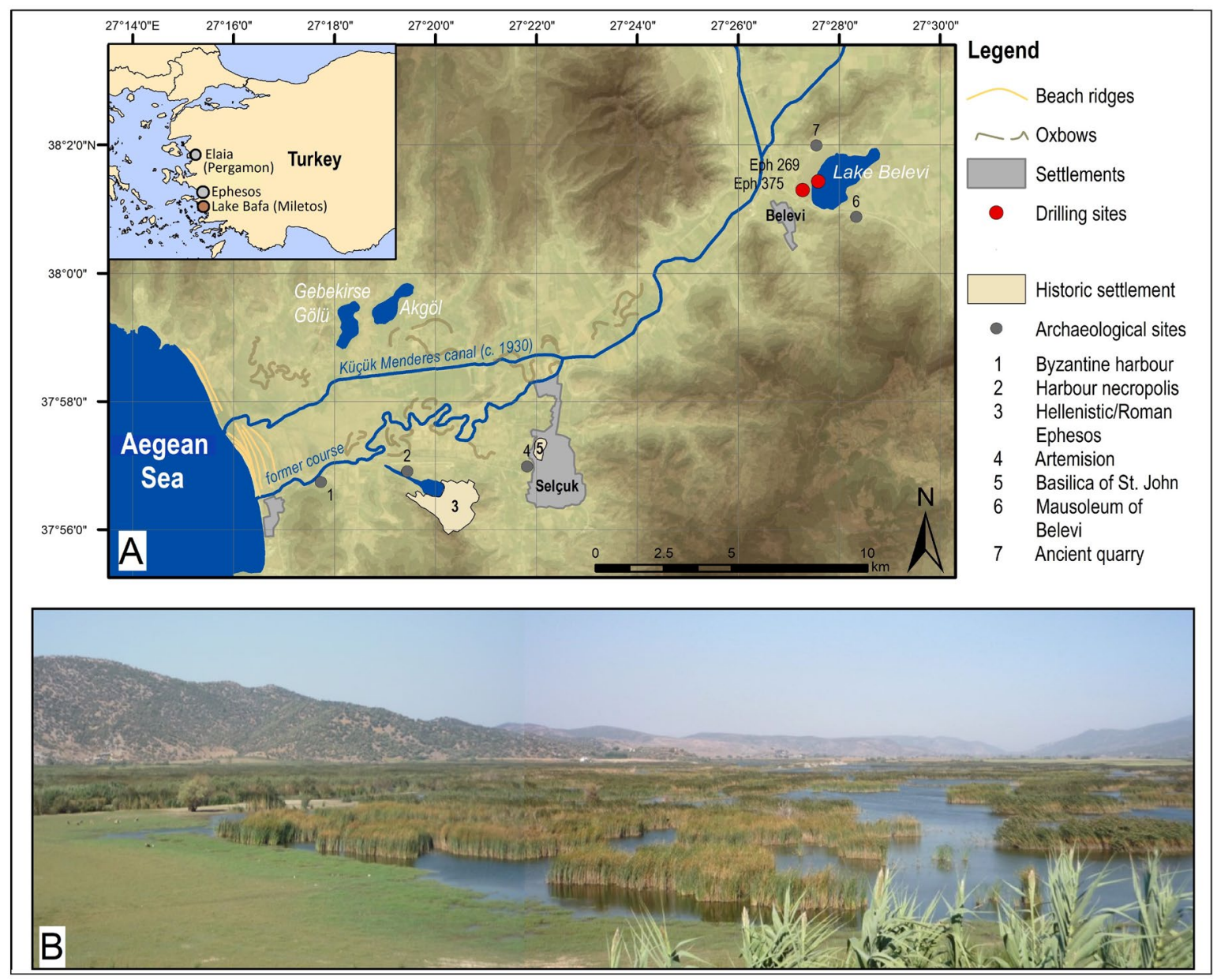

Fig. 1: Research area. A: Overview map of the environs of Ephesos and Lake Belevi (own design; source: Esri Digital Globe, GeoEye, Earthstar Geographics, CNES/Arirbus DS, USGS, AeroGRID; IGN and the GIS User Community). B: Southern shores of Lake Belevi, view in northeastern direction. Note the extended reed areas, which are cut for the production of wattlework (photo: Laermanns, 14 September 2011). 

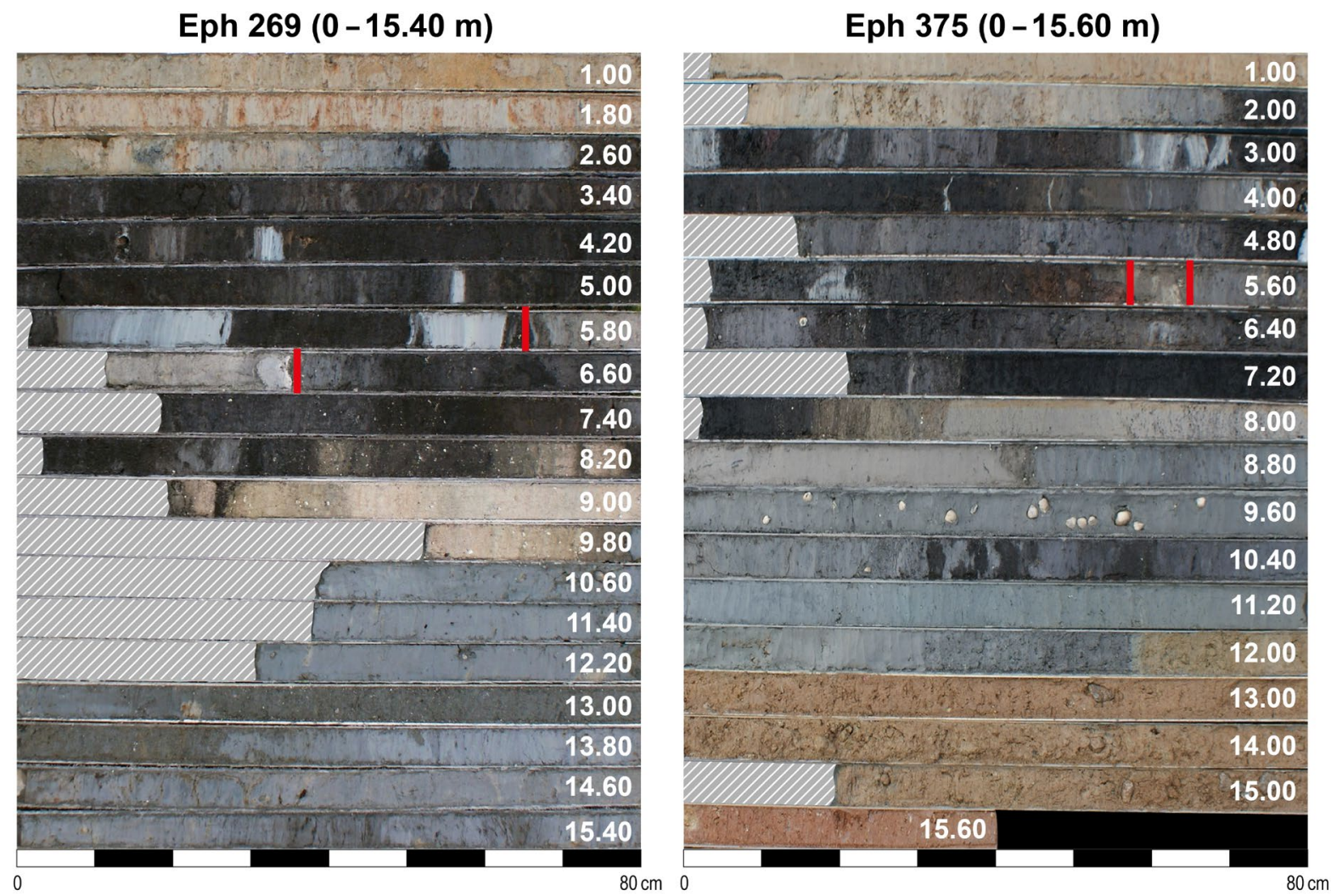

Fig. 2: Images of the sediment cores Eph 269 and Eph 375 (photos: Stock, 2011, 2013). Confined by red bars: Santorini tephra. Note that in most cases the coring progress was only $80 \mathrm{~cm}$ in order to have an overlap from one core-metre to the other to avoid collapsed material. Eph 269 is located at $3.46 \mathrm{~m}$ a.s.l., Eph 375 at $3.59 \mathrm{~m}$ a.s.l. Core sections with oblique hatching: collapsed material or void of sediment due to compaction. 

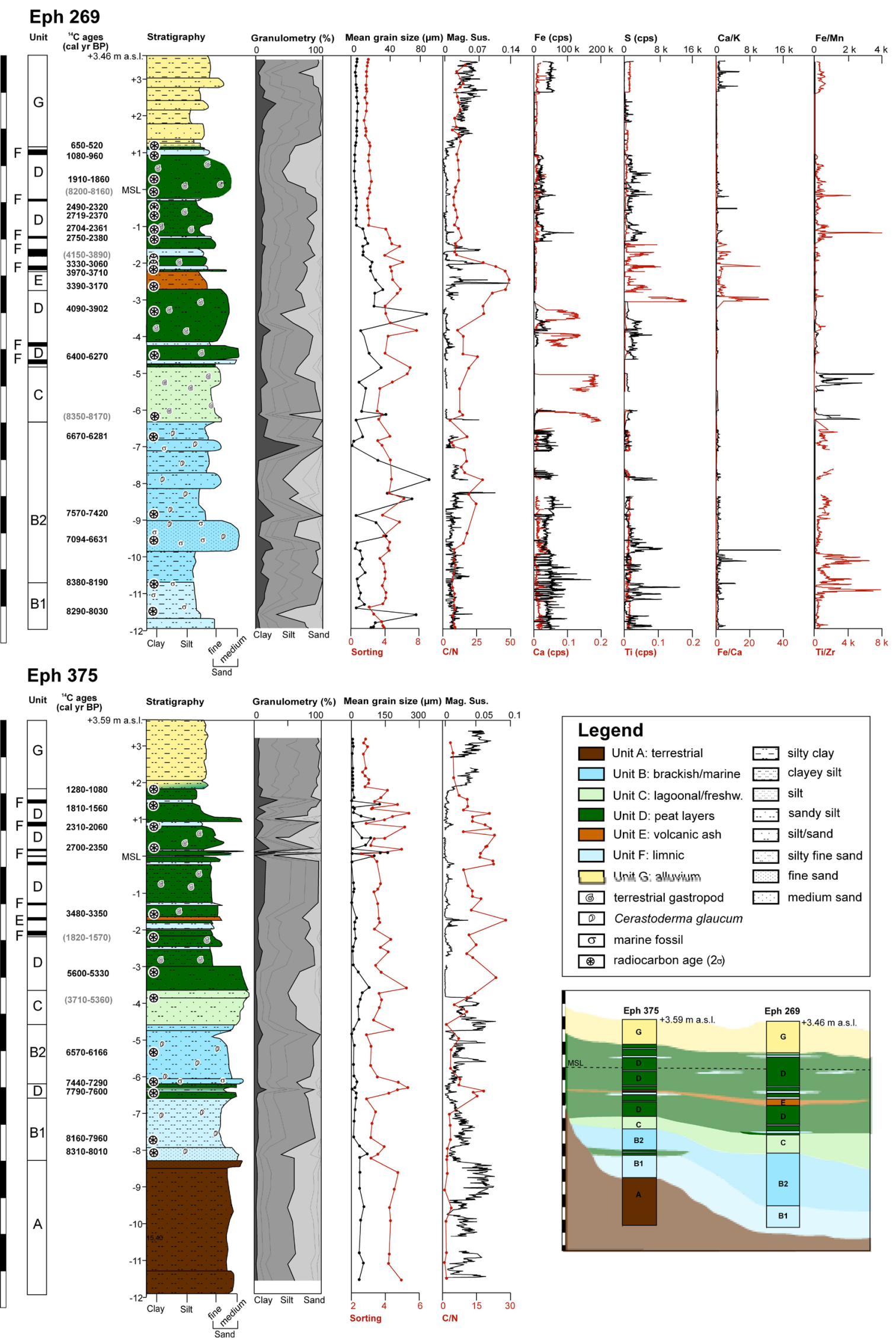

Fig. 3: Stratigraphy, sedimentology and geochemistry as well as ${ }^{14} \mathrm{C}$ age estimates of corings Eph 269 and Eph $375 .{ }^{14} \mathrm{C}$ age estimates in brackets and grey were not considered for the age-depth models. 

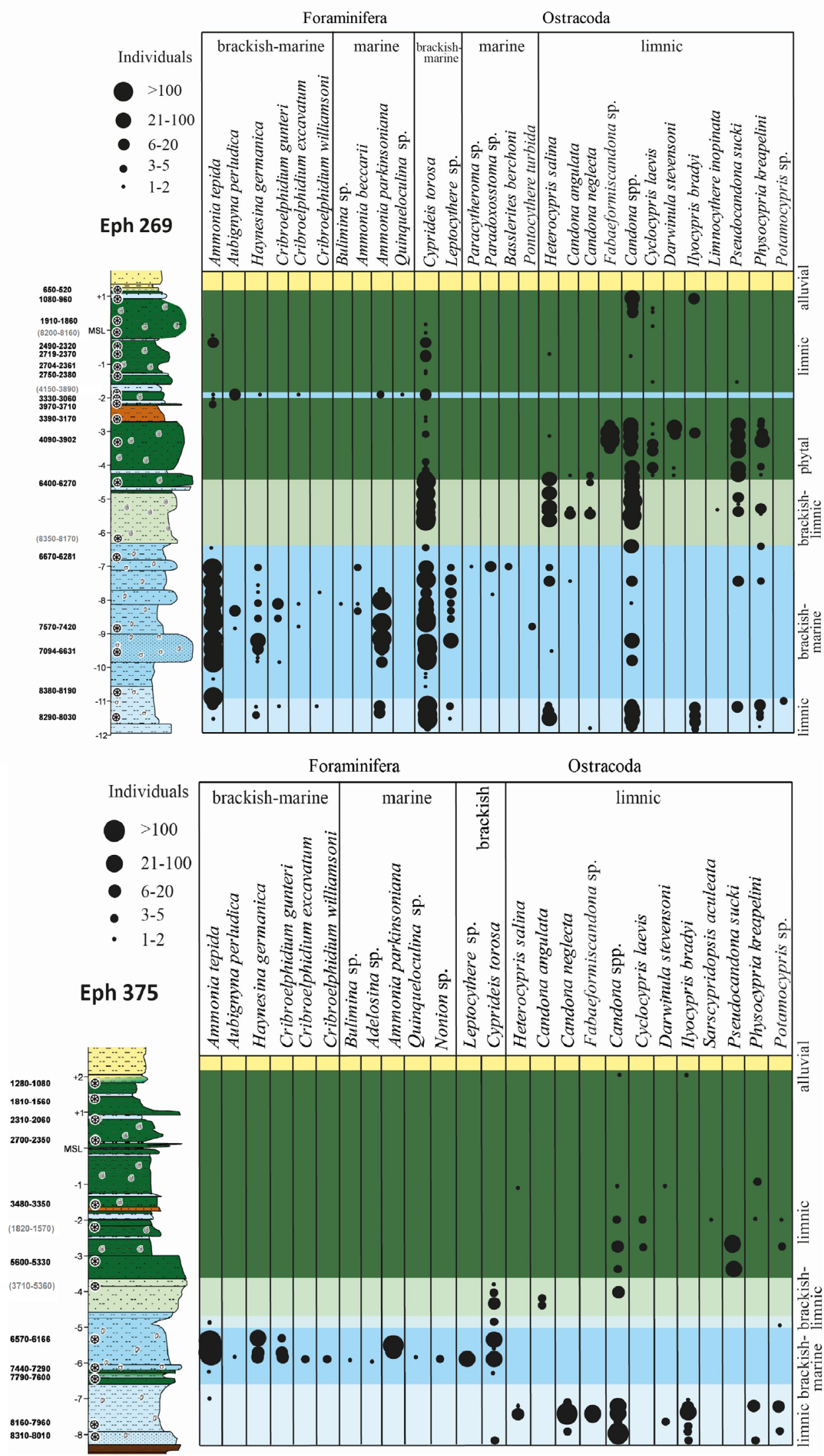

Fig. 4: Distribution of foraminifers and ostracods as well as differentiation into ecozones for cores Eph 269 and Eph 375. 


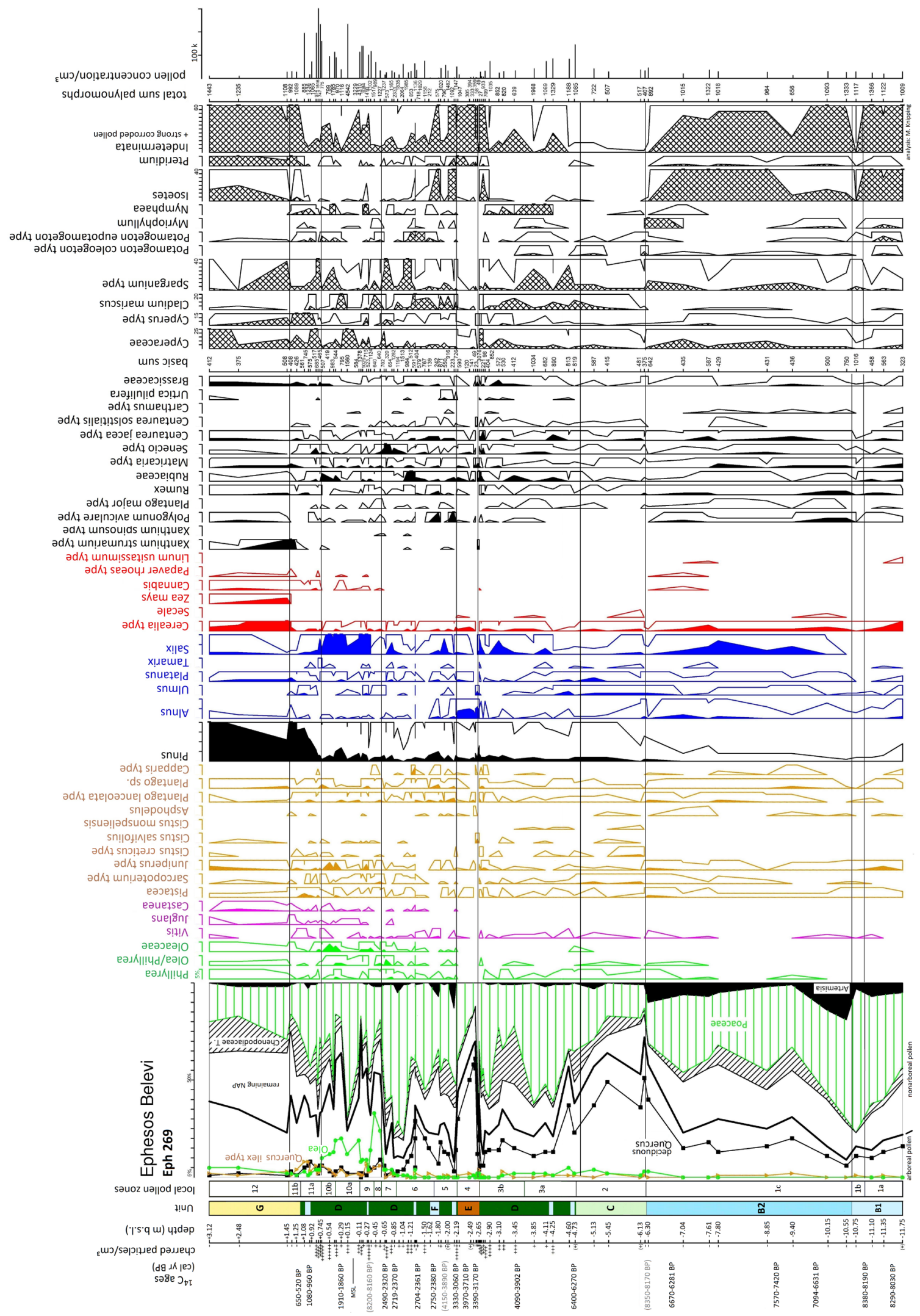

Fig. 5: Pollen diagram of sediment core Eph 269 from Belevi. The scale is always $5 \%$ with 10x exaggeration (thin line). 


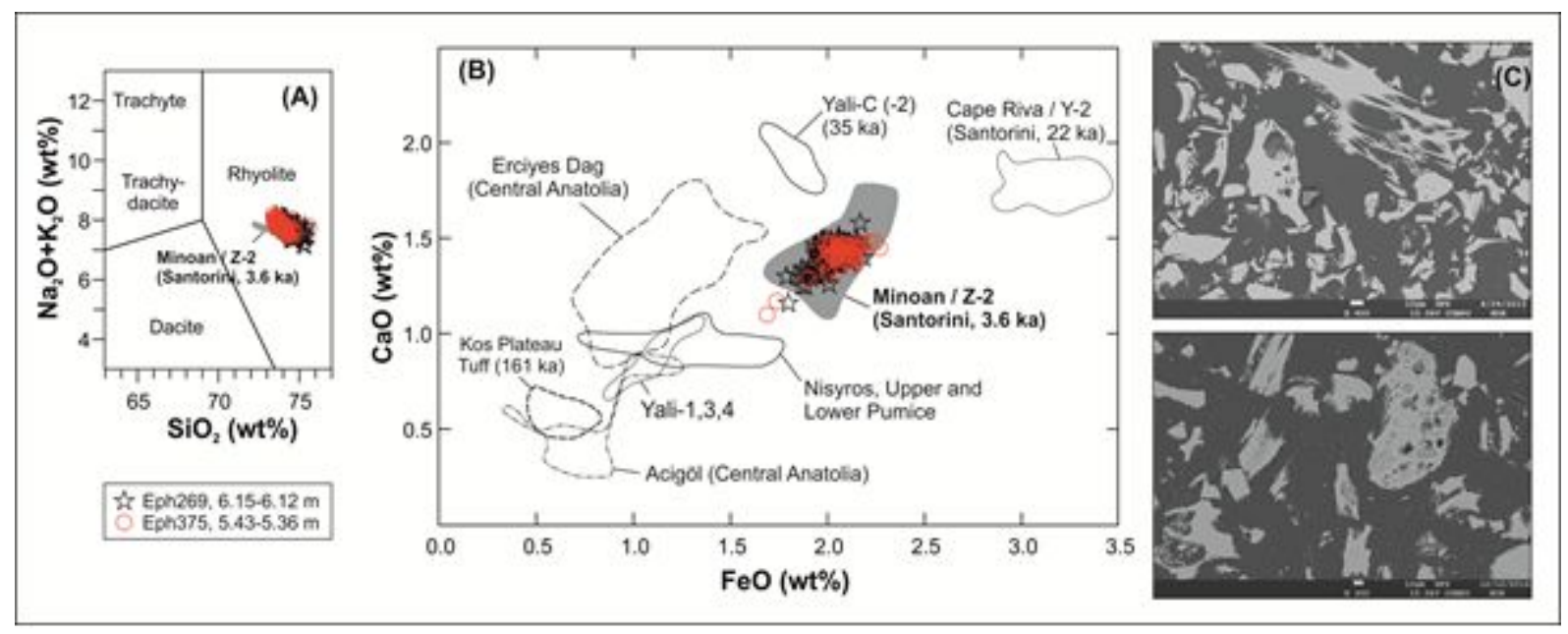

Fig. 6: Geochemical bi-plots of glass compositions of tephra layers from the cores Eph 269 and Eph 375 for (A) petrological classification (TAS diagram after Le Bas et al., 1986), and (B) comparison with potential tephra correlatives from Eastern Mediterranean volcanoes obtained from the literature (Erciyes Dağ: Hamann et al., 2010; Yali-C, Yali-1,3,4 Kos Plateau Tuff: Federman and Carey, 1980; Acigöl: Tomlinson et al., 2015; Nisyros: Tomlinson et al., 2012; Cape Riva/Y-2: Wulf et al., 2002; Minoan/Z2: Federman and Carey, 1980; Kwiecien et al., 2008; Wulf et al., 2020). Right side (C): Backscattered electron (BSE) image of volcanic glass shards of tephra samples from cores Eph 269 (upper right image) and Eph 375 (lower right image).
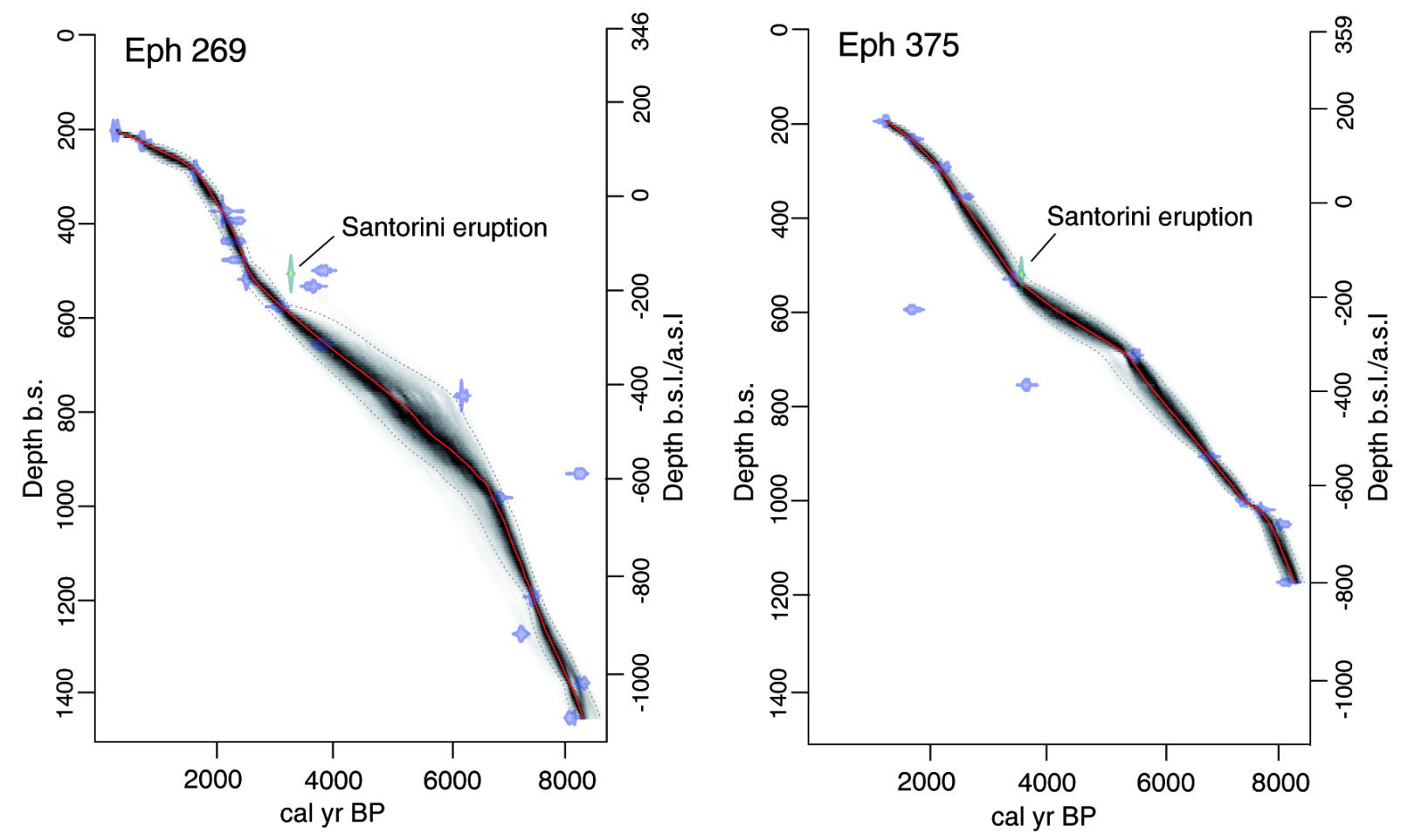

Fig. 7: Age-depth models for the sediment cores Eph 269 and Eph 375 from Lake Belevi (construction of the curves according to Blaauw and Christen, 2011). Depth in metres below surface (b.s.) and metres below/above sea level (b.s.l./a.s.l.). 


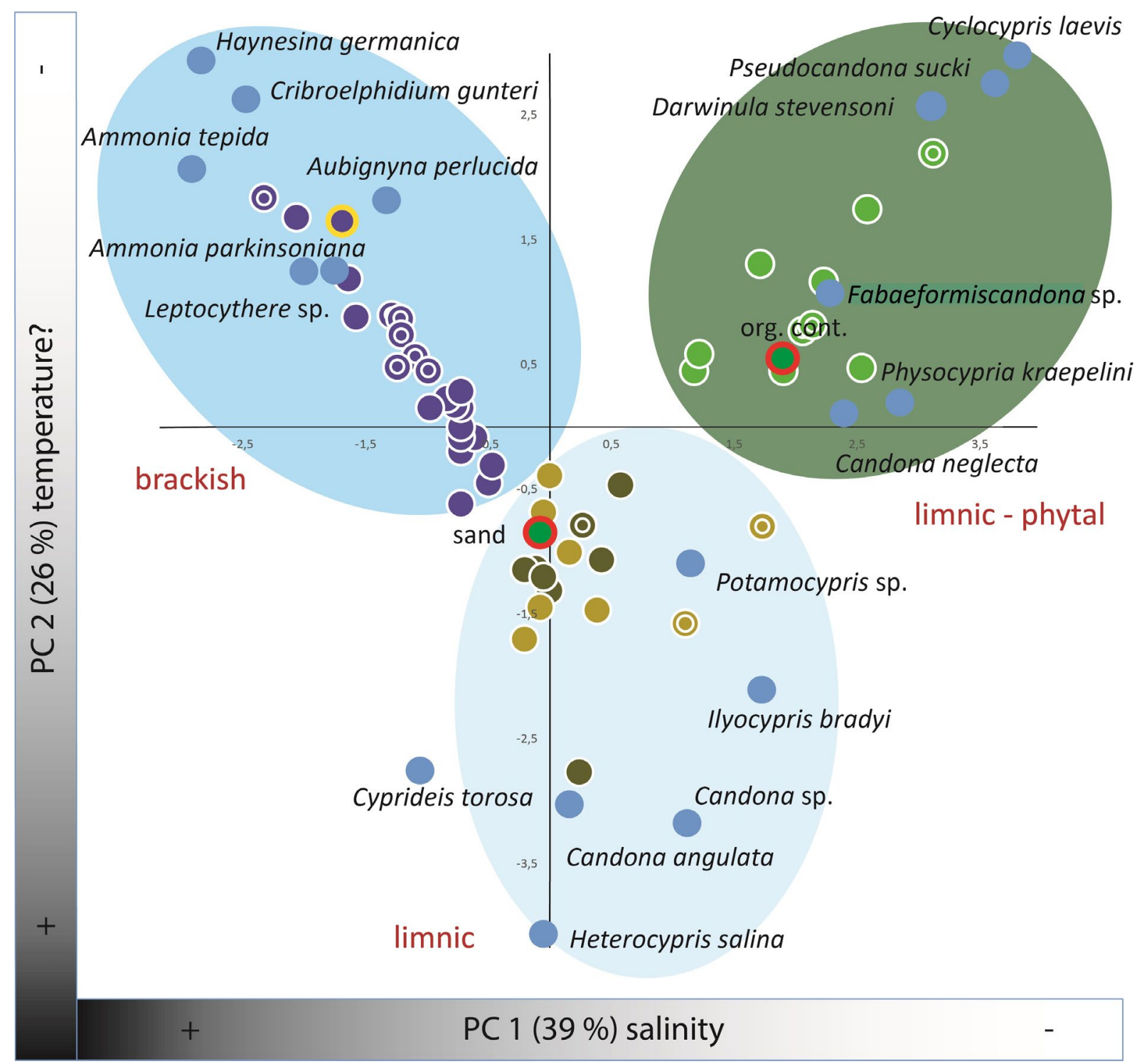

Fig. 8: Principal Component Analysis (PCA) with microfauna, loss of ignition (LOI) and sand samples of Eph 269 und 375. Large circles represent brackish (dark blue), limnic (light blue) and limnic-phytal (green) environments. Small circles represent selected samples from the drill cores (Eph 269: outer surrounding white circle; Eph 375: outer and inner white circles). Purple: brackish samples; yellow/olive, green: limnic samples; dark green: phytal-limnic samples; purple-yellow: brackish sample in peat of Eph 269; blue: load of the parameters (species), green-red: sand and organic content. PC 1: salinity, PC 2: temperature. 


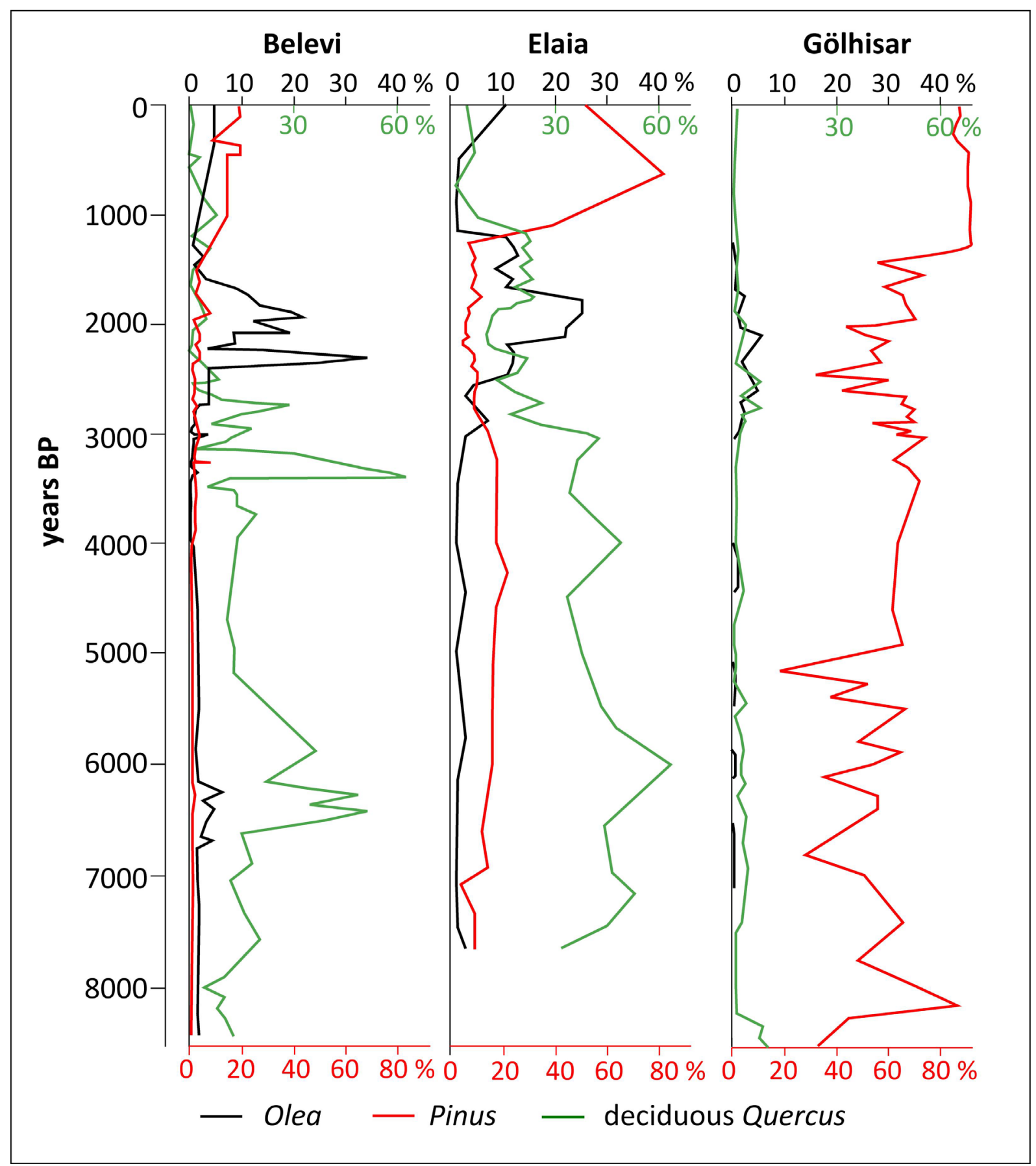

Fig. 9: Comparison of the three sites Belevi (this paper), Elaia (Shumilowski et al., 2016), and Gölhisar (Eastwood et al., 1999b) with selected pollen spectra: Olea, Pinus, deciduous Quercus-type (Belevi), Quercus robur-type (Elaia) and Quercus cerris-type (Gölhisar). The different pollen concentrations are represented in \% and plotted against age (up to 8500 years BP). 


\begin{tabular}{|c|c|c|c|c|c|c|c|c|}
\hline Sample code & Laboratory code & Unit & $\begin{array}{l}\text { Depth } \\
\mathrm{m} \text { b.s. }\end{array}$ & $\begin{array}{l}\text { Depth } \mathrm{m} \\
\text { b.s.l./a.s.I. }\end{array}$ & Material & $\begin{array}{l}\delta^{13} \mathrm{C} \\
(\% \circ)\end{array}$ & ${ }^{14} \mathrm{C}$ age $\mathrm{BP}$ & Age cal BP \\
\hline Eph 269/228-230 & UBA-34931 & D & 2.29 & 1.17 & bulk sample & -25.6 & $569 \pm 34$ & $650-520$ \\
\hline Eph 269/252 & UGAMS-13567 & $\mathrm{D}$ & 2.52 & 0.94 & organic matter & -8.7 & $1130 \pm 20$ & $1080-960$ \\
\hline Eph 269/317 & UBA-34849 & D & 3.17 & 0.29 & peat & -27.8 & $1960 \pm 25$ & $1910-1860$ \\
\hline Eph 269/377 & UBA-37376 & $\mathrm{D}$ & 3.77 & -0.31 & bulk sample & -24.6 & $7234 \pm 38$ & $(8200-8160)$ \\
\hline Eph 269/401-406 & UBA-34850 & D & 4.03 & -0.57 & rhizome & -26.3 & $2352 \pm 31$ & $2490-2320$ \\
\hline Eph 269/426 & UBA-37375 & $\mathrm{D}$ & 4.26 & -0.8 & seed, Corylus, plant & -23.8 & $2462 \pm 33$ & $2719-2370$ \\
\hline Eph $269 / 470$ & UBA-37374 & D & 4.7 & -1.24 & seed, Corylus, plant & -28.5 & $2449 \pm 31$ & $2704-2361$ \\
\hline Eph 269/508 & UBA-34851 & $\mathrm{D}$ & 5.08 & -1.62 & peat & -30.6 & $2498 \pm 47$ & $2750-2380$ \\
\hline Eph 269/530 & UBA-34852 & $\mathrm{D}$ & 5.3 & -1.84 & peat & -30.5 & $3677 \pm 38$ & $(4150-3890)$ \\
\hline Eph 269/550 & UBA-34853 & $\mathrm{D}$ & 5.5 & -2.04 & peat & -26.2 & $2981 \pm 30$ & $3330-3060$ \\
\hline Eph 269/564 & UBA-34854 & $\mathrm{D}$ & 5.64 & -2.18 & peat & -20 & $3553 \pm 36$ & $3970-3710$ \\
\hline Eph 269/609 & UBA-34855 & $\mathrm{F}$ & 6.09 & -2.63 & peat & -22.6 & $3086 \pm 43$ & $3390-3170$ \\
\hline Eph 269/690 & UBA-37377 & $\mathrm{D}$ & 6.9 & -3.44 & seed, Corylus, plant & -27.1 & $3670 \pm 32$ & 4090-3902 \\
\hline Eph 269/799-802 & UBA-34856 & $\mathrm{D}$ & 8.01 & -4.55 & freshwater snail (Gyraulus) & -8.1 & $5512 \pm 30$ & $6400-6270$ \\
\hline Eph 269/968 & UBA-34857 & c & 9.68 & -6.22 & Characeae oogonia & -17.5 & $7419 \pm 43$ & $(8350-8170)$ \\
\hline Eph 269/1021 & UGAMS-13570 & B2 & 10.21 & -6.75 & shell (Cerastoderma glaucum) & -4.6 & $6440 \pm 30$ & $6670-6281$ \\
\hline Eph 269/1233-1237 & UBA-34858 & B2 & 12.35 & -8.89 & charcoal & -20.9 & $6575 \pm 37$ & $7570-7420$ \\
\hline Eph 269/1315 & UGAMS-13568 & B2 & 13.15 & -9.69 & shell & -8.7 & $6760 \pm 30$ & $7094-6631$ \\
\hline Eph 269/1420 & UBA-34859 & B2 & 14.2 & -10.74 & rhizome & -23 & $7471 \pm 38$ & $8380-8190$ \\
\hline Eph 269/1496 & UGAMS-13569 & B2 & 14.96 & -11.5 & organic matter & -27.4 & $7320 \pm 30$ & $8290-8030$ \\
\hline Eph 375/193 & UBA-34870 & $\mathrm{D}$ & 1.93 & 1.66 & peat & -26.6 & $1257 \pm 29$ & $1280-1080$ \\
\hline Eph 375/231-233 & UBA-34871 & $\mathrm{D}$ & 2.32 & 1.27 & peat & -27.3 & $1763 \pm 33$ & $1810-1560$ \\
\hline Eph 375/290 & UBA-34872 & $\mathrm{D}$ & 2.9 & 0.69 & peat & -28.2 & $2167 \pm 29$ & $2310-2060$ \\
\hline Eph 375/353 & UBA-34873 & $\mathrm{D}$ & 3.53 & 0.06 & peat & -25.5 & $2435 \pm 28$ & $2700-2350$ \\
\hline Eph 375/528 & UBA-34874 & $\mathrm{D}$ & 5.28 & -1.69 & wood & -30.2 & $3187 \pm 33$ & $3480-3350$ \\
\hline Eph 375/593 & UBA-34875 & $\mathrm{D}$ & 5.93 & -2.34 & peat & -28.7 & $1768 \pm 37$ & $(1820-1570)$ \\
\hline Eph 375/690 & UBA-34876 & $\mathrm{D}$ & 6.9 & -3.31 & peat & -28.4 & $4781 \pm 34$ & $5600-5330$ \\
\hline Eph 375/754 & UBA-28141 & C & 7.54 & -3.95 & wood & -29.4 & $3393 \pm 31$ & $(3710-3560)$ \\
\hline Eph 375/905 & UBA-34877 & B2 & 9.05 & -5.46 & shell (Cerastoderma glaucum) & -9 & $6319 \pm 36$ & $6570-6166$ \\
\hline
\end{tabular}


POSTPRINT

\begin{tabular}{lllllllll} 
Eph $375 / 998$ & UBA-34878 & D & 9.98 & -6.39 & peat & -21.4 & $6455 \pm 37$ & $7440-7290$ \\
Eph $375 / 1018$ & UBA-34879 & D & 10.18 & -6.59 & peat & -26.4 & $6848 \pm 40$ & $7790-7600$ \\
Eph $375 / 1150$ & UBA-28142 & B2 & 11.5 & -7.91 & seed, Corylus, plant & -29.4 & $7220 \pm 45$ & $8160-7960$ \\
Eph 375/1173 & UBA-28144 & B1 & 11.73 & -8.14 & seed, Corylus, plant & -28.2 & $7326 \pm 54$ & $8310-8010$ \\
\hline
\end{tabular}

Table 1: Radiocarbon ages. The age estimates are presented as conventional and calibrated ages and calculated with a standard deviation of $2 \sigma$ (probability of 95.5\%). All ages were calibrated with Calib 7.1 (data set: Intcal 13; Reimer et al., 2013). Marine samples were corrected with a marine reservoir effect of $390 \pm 85$ years and $\Delta \mathrm{R}=35 \pm 70$ years (for mollusc shell Cerastoderma glaucum; Siani et al., 2000). Depth b.s. (below surface); depth b.s.l./a.s.l. (below/above sea level). UGAMS: Center for Applied Isotope Studies, University of Georgia, USA; UBA: The 14CHRONO Centre, Queen's University Belfast, UK. The numbers in brackets are rejected ages.

Supplement 1: Results of the tephra analysis.

Supplement 2: Pollen raw data. 